WSRC-TR-2001-00591 Rev 0

SRT-RPP-2001-00227 Rev 0

\title{
DESIGN ANALYSIS FOR A SCALED EROSION TEST
}

\author{
UNCLASSIFIED \\ DOES NOT CONTAIN \\ UNCLASSIFIED CONTROLLED \\ NUCLEAR INFORMATION \\ $\mathrm{ADC} \&$ \\ Reviewing \\ Official: \\ (Name and Title) \\ Date:
}

Disclaimer

This report was prepared by Westinghouse Savannah River Company (WSRC) for the United States Department of Energy under Contract No. DE-AC09-96SR18500 and is an account of work performed under that contract. Neither the United States Department of Energy, nor WSRC, nor any of their employees makes any warranty, expressed or implied, or assumes any legal liability or responsibility for accuracy, completeness, or usefulness, of any information, apparatus, or product or process disclosed herein or represents that its use will not infringe privately owned rights. Reference herein to any specific commercial product, process, or service by trade name, trademark, name, manufacturer or otherwise does not necessarily constitute or imply endorsement, recommendation, or favoring of same by WSRC or by the United States Government or any agency thereof. The views and opinions of the authors expressed herein do not necessarily state or reflect those of the United States Government or any agency thereof.

Westinghouse Savannah River Company

Savannah River Site

Aiken, SC 29808

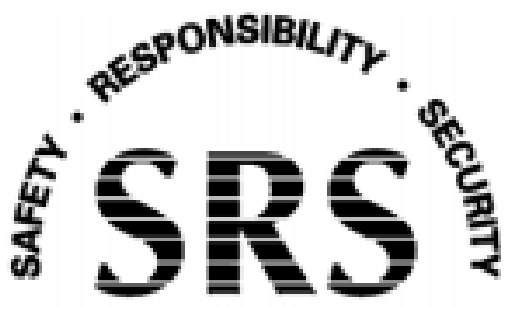

Prepared for the U.S. Department of Energy under Contract No. DE-AC09-96SR18500 
This document was prepared in conjunction with work accomplished under Contract No. DEAC09-96SR18500 with the U.S. Department of Energy.

\section{DISCLAIMER}

This report was prepared as an account of work sponsored by an agency of the United States Government. Neither the United States Government nor any agency thereof, nor any of their employees, makes any warranty, express or implied, or assumes any legal liability or responsibility for the accuracy, completeness, or usefulness of any information, apparatus, product or process disclosed, or represents that its use would not infringe privately owned rights. Reference herein to any specific commercial product, process or service by trade name, trademark, manufacturer, or otherwise does not necessarily constitute or imply its endorsement, recommendation, or favoring by the United States Government or any agency thereof. The views and opinions of authors expressed herein do not necessarily state or reflect those of the United States Government or any agency thereof.

This report has been reproduced directly from the best available copy.

Available for sale to the public, in paper, from: U.S. Department of Commerce, National Technical Information Service, 5285 Port Royal Road, Springfield, VA 22161

phone: (800) 553-6847

fax: (703) 605-6900

email: orders@ntis.fedworld.gov

online ordering: http://www.ntis.gov/support/index.html

Available electronically at http://www.osti.gov/bridge

Available for a processing fee to U.S. Department of Energy and its contractors, in paper, from: U.S. Department of Energy, Office of Scientific and Technical Information, P.O. Box 62, Oak Ridge, TN 37831-0062

phone: (865)576-8401

fax: (865)576-5728

email: reports@adonis.osti.gov 
WSRC-TR-2001-00591

SRT-RPP-2001-00227

KEYWORDS:

Hanford River Protection Project Computational Approach Erosion Model

Particle Impingement Model

\section{DESIGN ANALYSIS FOR A SCALED EROSION TEST}

SAVANNAH RIVER TECHNOLOGY CENTER

Si Young Lee and Richard A. Dimenna

April 2002

Westinghouse Savannah River Company

Savannah River Site

Aiken, SC 29808

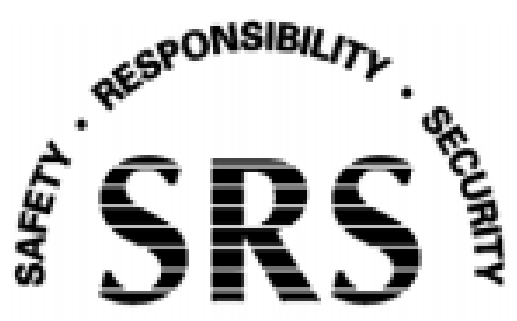

SAVANNAH RIVER SITE

Prepared for the U.S. Department of Energy under Contract No. DE-AC09-96SR18500

WSRC-TR-2001-00591

SRT-RPP-2001-00227 
(This Page Intentionally Left Blank) 
DOCUMENT:WSRC-TR-2001-00591 (SRT-RPP-2001-00227)

TITLE: DESIGN ANALYSIS FOR A SCALED EROSION TEST

\section{APPROVALS}

Si Y. Lee, Author (EM\&S Group/ SRTC)

Date:

Date:

Richard A. Dimenna, Co-Author (EM\&S Group/ SRTC)

Date:

Reid A. Peterson, RPP-WTP (WGI)

Cynthia P. Holding-Smith, Manager (EM\&S Group/SRTC)

Date:

Date:

Steve T. Wach, Manager (EDS/SRTC)

Hector N. Guerrero, Technical Reviewer (EDS/SRTC)

Date: 
WSRC-TR-2001-00591

SRT-RPP-2001-00227

(This Page Intentionally Left Blank) 


\section{Table of Contents}

List of Figures $\quad$ vii

List of Tables $\quad$ ix

Nomenclature $\quad$ xi

$\begin{array}{ll}\text { Abstract } & 1\end{array}$

1 Introduction 1

2. Analysis Approach and Methodology 6

2.1 Principal Mechanisms for the Present Analysis ............................................ 7

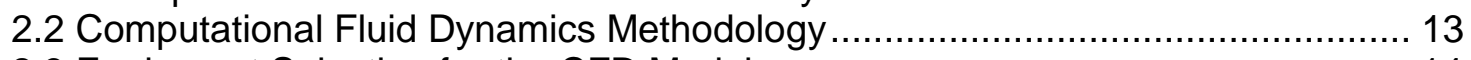

2.3 Equipment Selection for the CFD Model.................................................. 14

3. Modeling Assumptions and Computational Domains 17

4. Results and Discussions 22

4.1 Benchmarking Results of the Present Model ................................................ 22

4.2 Results of the Design information and Operational Guidance for Scaled

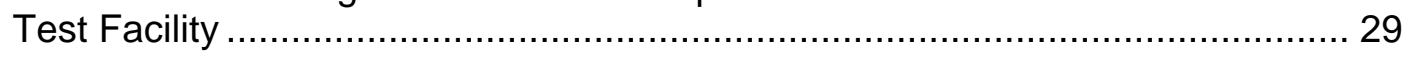

5. Conclusions 56

$\begin{array}{ll}\text { 6. References } & 58\end{array}$ 
WSRC-TR-2001-00591

SRT-RPP-2001-00227

(This Page Intentionally Left Blank) 


\section{List of Figures}

Figure 1. Schematic of the cross-flow filtration facility representing key loop components for the design analysis.

Figure 2. Schematic representation of solid concentration and velocity distributions for various flow regimes of solids-laden slurry $\left(\mathrm{V}_{\mathrm{c}}\right.$ is a critical velocity to initiate the movement of particle from the deposit area as shown in Table 2.).

Figure 3. Main driving mechanisms of erosion in a slurry flow for the present analysis....... 10

Figure 4. Equipment components contained in the full-scale filtration facility shown in Fig. 1, which used in the present study of equipment selection.

Figure 5. Computational domain and meshes of the three-dimensional model for the standard isolated elbow component for the present analysis $\left(U_{\text {avg }}=9.8 \mathrm{ft} / \mathrm{sec}\right.$ corresponding to $2400 \mathrm{gpm}$ slurry flow in 10 in pipe).

Figure 6. Modeling domain boundary and computational meshes of the central twodimensional plane of three-dimensional model for the horizontal S-type pipe component including two standard elbows

Figure 7. Three-dimensional computational domains and their meshes for the center plane of the one tube filter models with smooth filter tube and 5 mils mismatched tube due to the welded connection.

Figure 8. Three-dimensional computational domain and its meshes of the 7-tube filter model for the upstream region of the cross-flow filter component.

Figure 9. Test sections of the two elbows used in the slurry experiments [15] ..................2 23

Figure 10. Comparison of predictions with the test data available in the literature [15] using the standard $\kappa-\varepsilon$ turbulent model.

Figure 11. Erosion contour plot due to the particle impingement for horizontal pipe available in the literature [13] using standard $\kappa-\varepsilon$ turbulent model.

Figure 12. Solid concentrations of slurry flow at the exit plane of the horizontal pipe available in the literature experiment [13] using a standard $k-\varepsilon$ turbulent model...

Figure 13. Comparison of predictions with the erosion test data for horizontal pipe available in the literature [13] using the standard $\kappa-\varepsilon$ turbulent model with discrete solid phase.

Figure 14. Velocity and turbulence distributions at the center plane of an isolated elbow component in a full-scale filtration system (The bottom side of the elbow shown above is fluid inlet.).

Figure 15. Radial velocity distributions at the cross-sectional planes of the upstream and downstream regions of the elbow component.

Figure 16. Turbulence intensities at the cross-sectional planes of the upstream and downstream regions of the elbow component.

Figure 17. Vorticity magnitudes at the cross-sectional planes of the upstream and downstream regions of the elbow component.

Figure 18. Wall shear stress distributions for a slurry flow in isolated elbow.

Figure 19. Particle trajectory and erosion distributions due to the impingement of particles in a slurry.

Figure 20. Comparison of turbulence intensity for two cases associated with particle dispersion. 


\section{WSRC-TR-2001-00591 \\ SRT-RPP-2001-00227}

Figure 21. Wall shear stress and turbulence intensity distributions for the 36 in long and 10 in diameter pipe with 3 in leg (case g) associated with wall erosion.

Figure 22. Comparison of velocity distributions at the center planes of the one-tube models with smooth and welded tubes (case-e and case-f in Fig. 4).

Figure 23. Comparison of velocity distributions at the center plane of the one-tube and seven-tube filter models to simulate the cross-flow filtration component.

Figure 24. Comparison of turbulence intensity distributions at the center plane of the one-tube and seven-tube filter models to simulate the cross-flow filtration component using flow domains and conditions shown in Figs. 7 and 8.

Figure 25. Comparison of wall shear distributions between one-tube model and 7-tube model to simulate the cross-flow filtration system.

Figure 26. Comparison of erosion distributions for the two filter models

Figure 27. Potential maximum erosion locations at the middle planes of one-tube (case-

e) and seven-tube filter (case-g) components of the cross-flow filtration facility predicted by the present model.

Figure 28. Velocity vector plot at the center plane of the 7-tube model.

Figure 29. Pressure distributions at the center plane of the 7-tube model.

Figure 30. Wall shear distributions for the bluff body (case-i in Fig 4) predicted by the present model.

Figure 31. Particle trajectories for the bluff body inside the straight pipe (case-i in Fig 4) predicted by the particle impingement model.

Figure 32. Potential maximum erosion locations at the middle planes of key components of the cross-flow filtration facility selected by the present model.

Figure 33. Comparison of the erosion distributions due to particle impingement under three different scaled elbow components ....

Figure 34. Nondimensional erosion ratio of scale-down (3 in and $1 \mathrm{in}$ ) to 10 in prototypic elbow for various slurry velocities....

Figure 35. Nondimensional erosion ratio of scale-down (3 in and $1 \mathrm{in}$ ) to 10 in prototypic S-type pipings for various slurry velocities

Figure 36. Nondimensional erosion ratio of scale-down (3 in and 1 in) to 10 in prototypic bluff body for various slurry velocities. 


\section{List of Tables}

Table 1. Design and operating conditions of the full-scale cross-flow filtration system used in the present analysis.

Table 2. Critical velocities to initiate the particle movement and average flow velocities for various scaled facilities (particle diameter $=10$ microns) 7

Table 3. Primary purposes of the CFD models used in the present analysis. ................... 13

Table 4. Test conditions for the pressure drop measurements across the elbows .............. 24

Table 5. Test conditions of the literature data [13] used in the present benchmarking of the present erosion model

Table 6. Maximum shear stresses and relative maximum erosion for the elbows with different curvature

Table 7. Maximum wall shear stresses for the cases considered in the analysis associated with erosion ( $D=10$ in and $d=3$ in)

Table 8. Maximum wall shear stresses for the models of the filter component associated with erosion (filter tube diameter $=0.5 \mathrm{in}$ )

Table 9. Maximum wall shears for the models of the key components considered in the analysis associated with erosion (filter tube diameter $=0.5 \mathrm{in}$ ). 
WSRC-TR-2001-00591

SRT-RPP-2001-00227

(This Page Intentionally Left Blank) 


\section{Nomenclature}

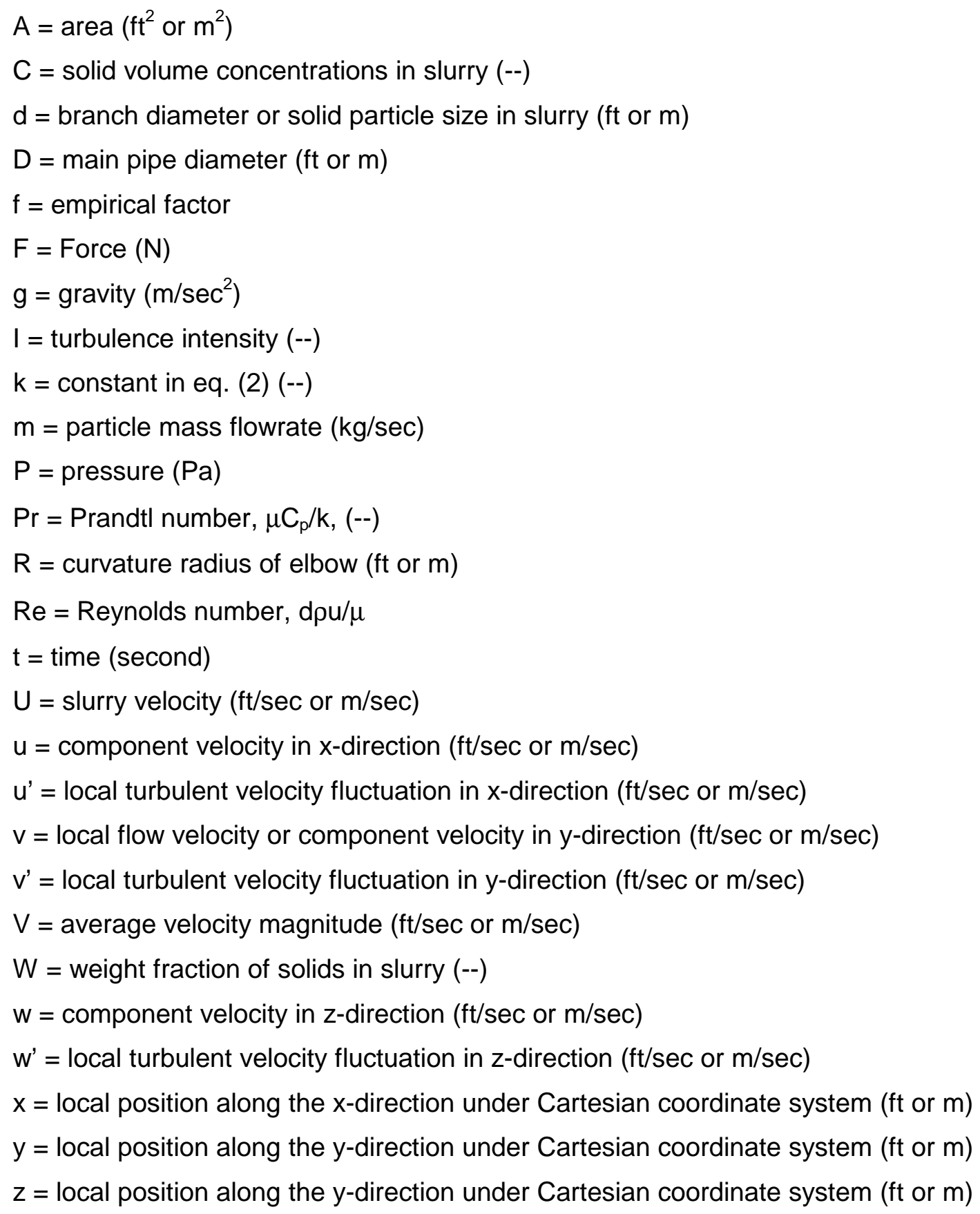




\section{Greek}

$\rho=$ density $\left(\mathrm{kg} / \mathrm{m}^{3}\right)$

$\beta=$ impingement angle of particle against wall surface

$\kappa=$ turbulent kinetic energy $\left(=\frac{1}{2}\left(u^{\prime 2}+v^{\prime 2}+w^{\prime 2}\right)_{\text {avg }}\right)$

$\varepsilon=$ rate of dissipation of turbulent kinetic energy

$\Delta=$ difference

$\nabla=$ gradient operator

$\mu=$ dynamic viscosity $\left(\mathrm{N} \mathrm{sec} / \mathrm{m}^{2}\right)$

$v=$ kinematic viscosity $\left(\mathrm{m}^{2} / \mathrm{sec}\right)$

$\xi=$ empirical facto for erosion rate

\section{Subscript}

$$
\begin{aligned}
& \text { avg = average } \\
& c=\text { critical } \\
& d=\text { incident particle } \\
& f=\text { fluid } \\
& \text { in = incidence } \\
& p=\text { particle } \\
& s=\text { solid particle } \\
& t=\text { turbulent } \\
& \text { wall = wall surface }
\end{aligned}
$$




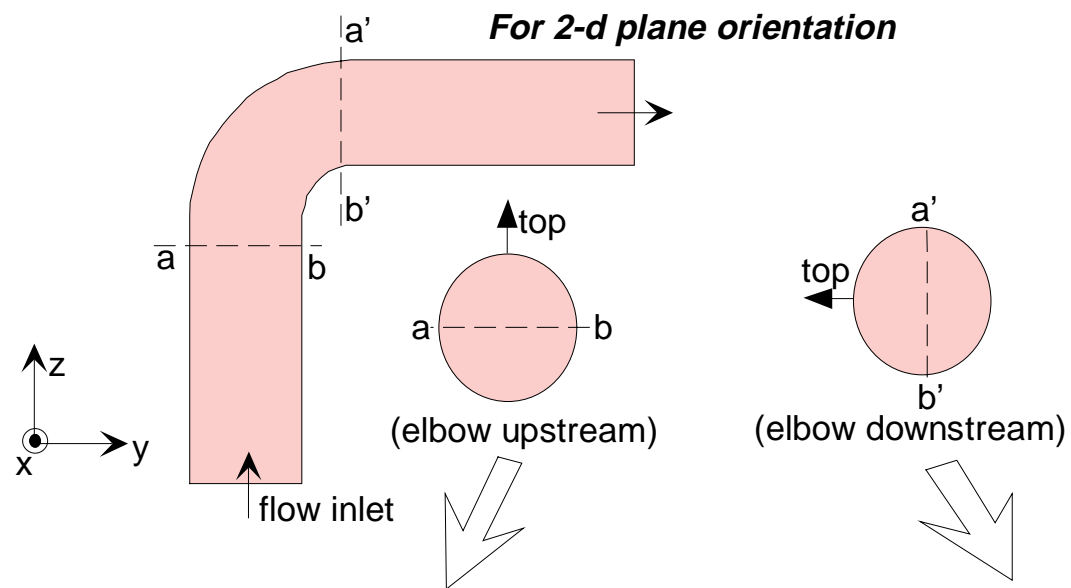

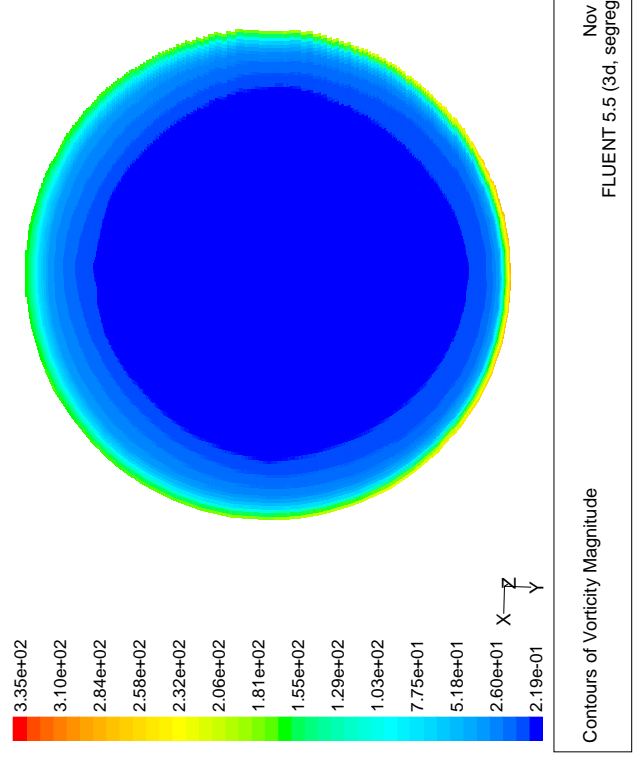

(elbow upstream)

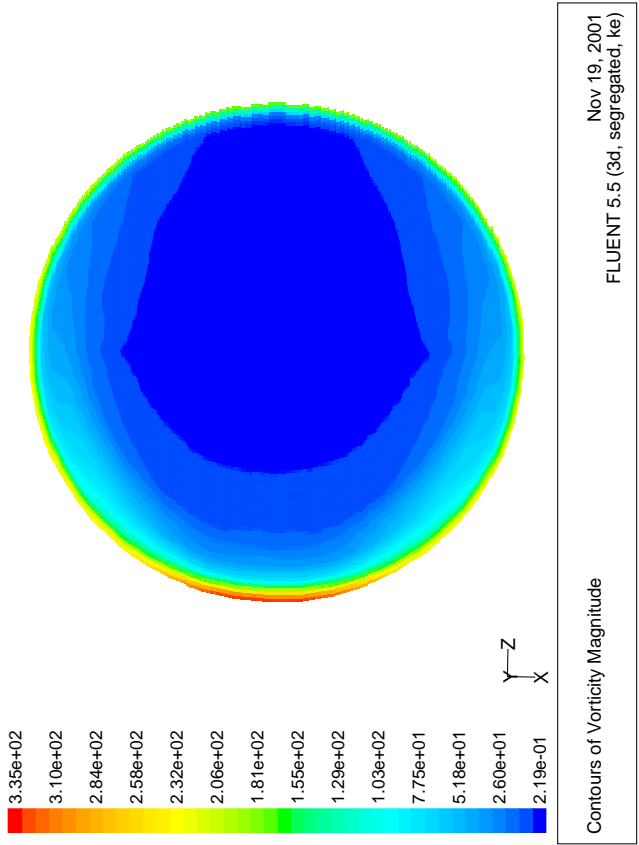

(elbow downstream)

Figure 17. Vorticity magnitudes at the cross-sectional planes of the upstream and downstream regions of the elbow component. 
Report: WSRC-TR-2001-00591 Rev 0 SRT-RPP-2001-00227 Rev 0

Date: $\quad 04 / 05 / 02$

Page: 36 of 60
WESTINGHOUSE SAVANNAH RIVER COMPANY

DESIGN ANALYSIS FOR A SCALED EROSION TEST
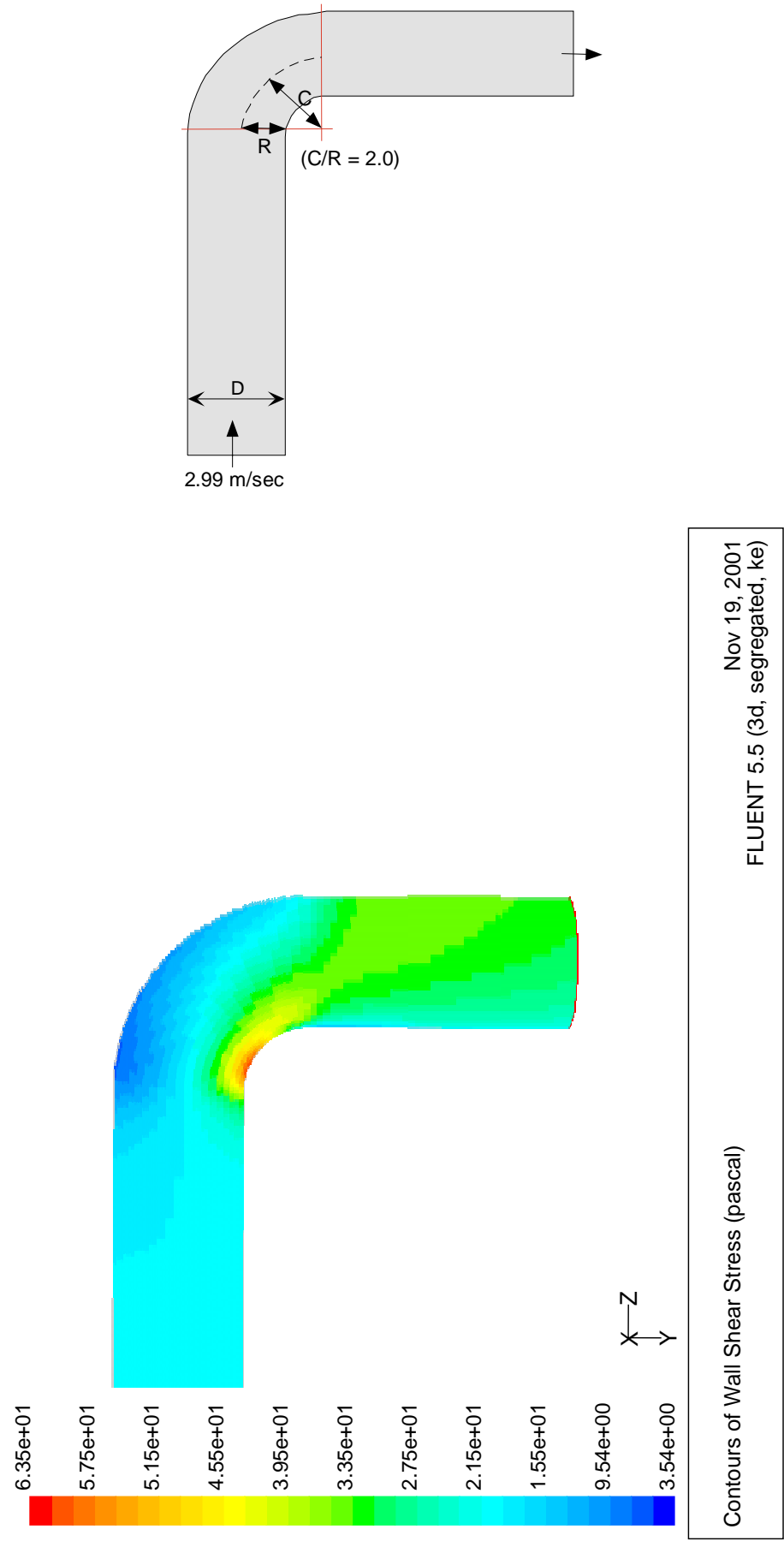

Figure 18. Wall shear stress distributions for a slurry flow in isolated elbow. 
Date:

$04 / 05 / 02$

Page:

37 of 60

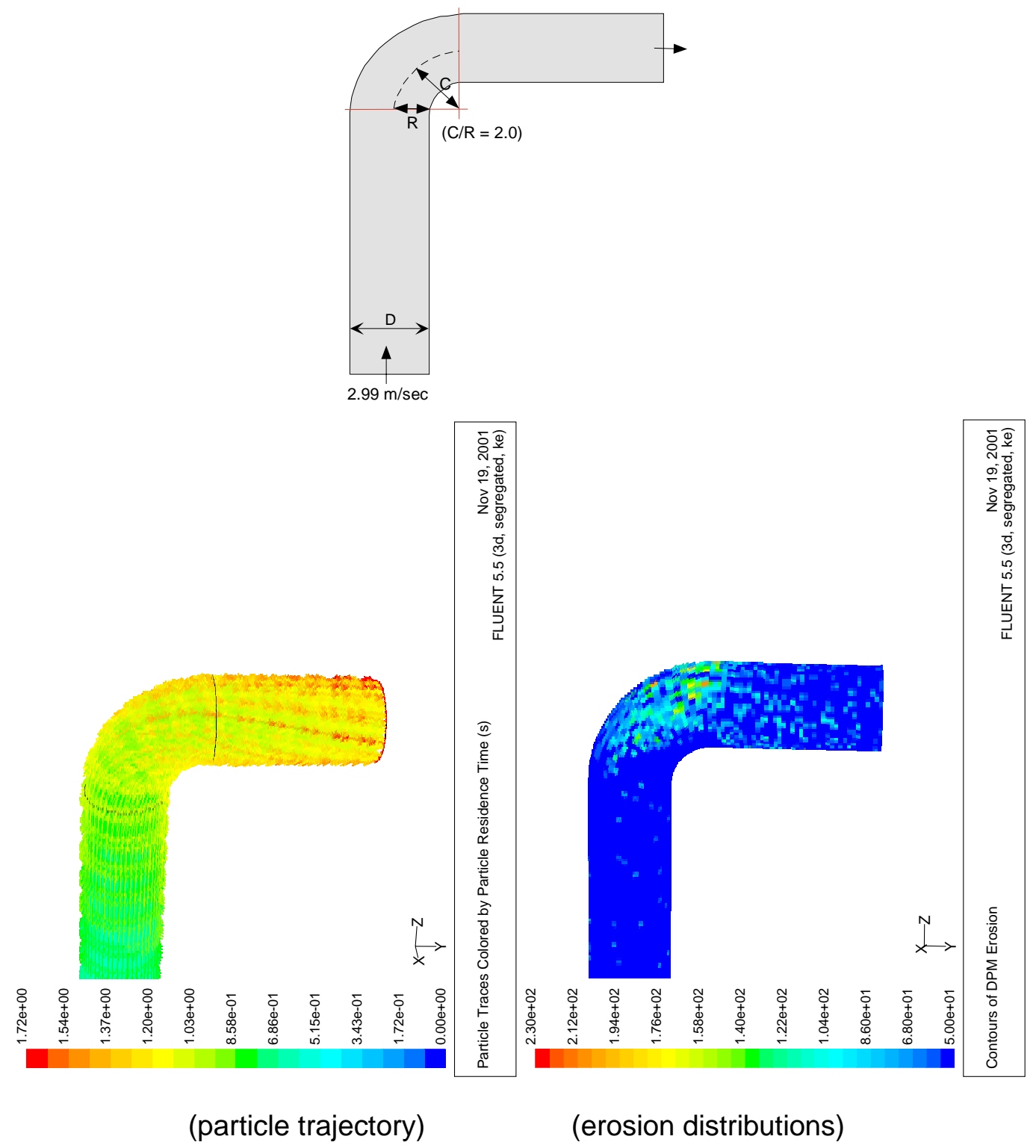

Figure 19. Particle trajectory and erosion distributions due to the impingement of particles in a slurry. 
Report: WSRC-TR-2001-00591 Rev 0 SRT-RPP-2001-00227 Rev 0

Date: $\quad 04 / 05 / 02$

Page: 38 of 60
WESTINGHOUSE SAVANNAH RIVER COMPANY

DESIGN ANALYSIS FOR A SCALED EROSION TEST

Table 6. Maximum shear stresses and relative maximum erosion for the elbows with different curvature

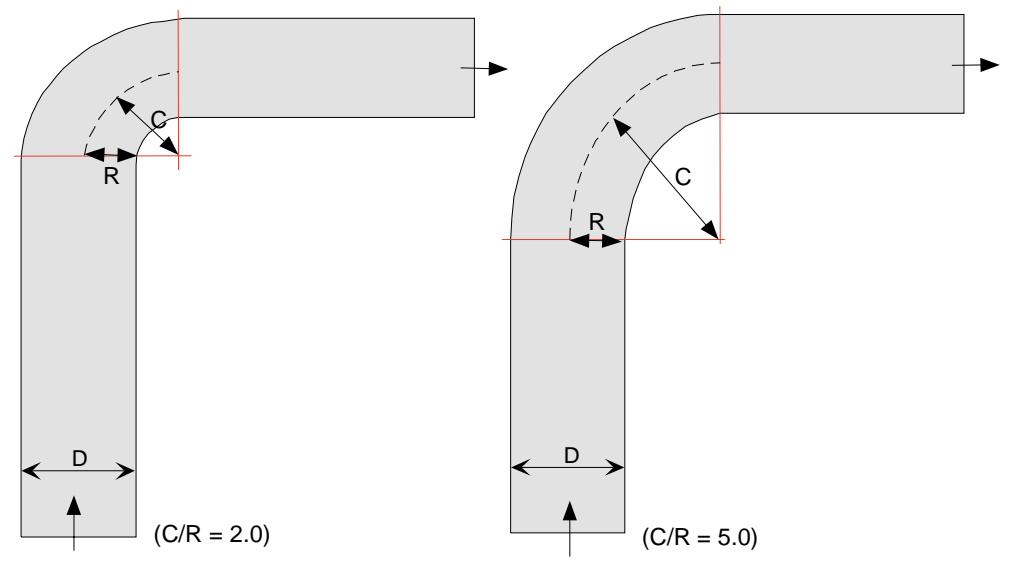

\begin{tabular}{|c|c|c|}
\hline Elbow Curvature (C/R) & 2.0 & 5.0 \\
\hline Flowrate & $2400 \mathrm{gpm}$ & $2400 \mathrm{gpm}$ \\
\hline Elbow Diameter & $10 \mathrm{in}$ & $10 \mathrm{in}$ \\
\hline Max. Wall Shear & $67.2 \mathrm{~Pa}$ & $31.6 \mathrm{~Pa}$ \\
\hline Relative scale for erosion rate & 1.0 & $\sim 0.65$ \\
\hline
\end{tabular}


WESTINGHOUSE SAVANNAH RIVER COMPANY

DESIGN ANALYSIS FOR A SCALED EROSION TEST
Report: WSRC-TR-2001-00591 Rev 0 SRT-RPP-2001-00227 Rev 0

Date:

Page:
$04 / 05 / 02$

39 of 60

Table 7. Maximum wall shear stresses for the cases considered in the analysis associated with erosion ( $D=10$ in and $d=3$ in)

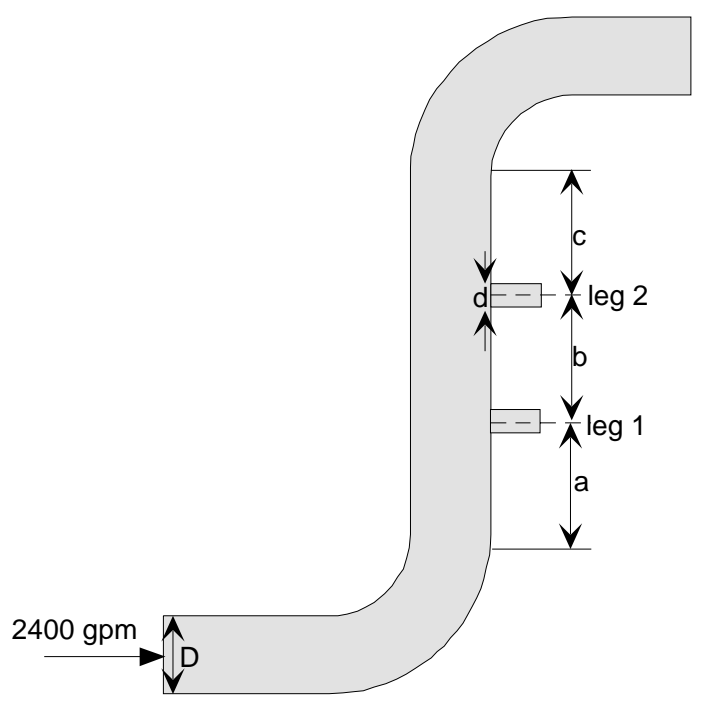

\begin{tabular}{|c|c|c|c|c|c|c|c|}
\hline Cases (Fig. 4) & Case-b & \multicolumn{5}{|c|}{ Case-c } & Case-d \\
\hline $\begin{array}{l}\text { Presence (?) of } \\
\text { elbows at the } \\
\text { downstream and } \\
\text { upstream regions } \\
\text { of the 10" pipe }\end{array}$ & Yes & Yes & Yes & Yes & Yes & Yes & $\begin{array}{l}\text { No (10in } \\
\text { diameter } \\
\text { and } 36 \mathrm{in} \\
\text { long pipe) }\end{array}$ \\
\hline Number of legs & 2 & $1(\log 1)$ & $1(\operatorname{leg} 2)$ & $1(\operatorname{leg} 1)$ & $1(\operatorname{leg} 1)$ & $1(\operatorname{leg} 1)$ & $1(\operatorname{leg} 1)$ \\
\hline $\begin{array}{c}\text { Total length } \\
\text { between elbows }\end{array}$ & 36in & 36 in & 36in & 33in & 30in & 72in & 36 in \\
\hline a & 12in & 12in & 12in & 9in & 9in & 9in & $12 \mathrm{in}$ \\
\hline$b$ & $12 \mathrm{in}$ & 12in & 12in & 12in & 12in & 12in & -- \\
\hline C & $12 \mathrm{in}$ & 12in & 12in & 12in & 9in & 51 in & -- \\
\hline $\begin{array}{l}\text { Max. wall shear } \\
(\mathrm{Pa})\end{array}$ & 62.6 & 63.7 & 63.2 & 64.7 & 66.2 & 62.9 & 40 \\
\hline
\end{tabular}


Report: WSRC-TR-2001-00591 Rev 0

Date: $\quad 04 / 05 / 02$

DESIGN ANALYSIS FOR A SCALED EROSION TEST

\section{Page: $\quad 40$ of 60}

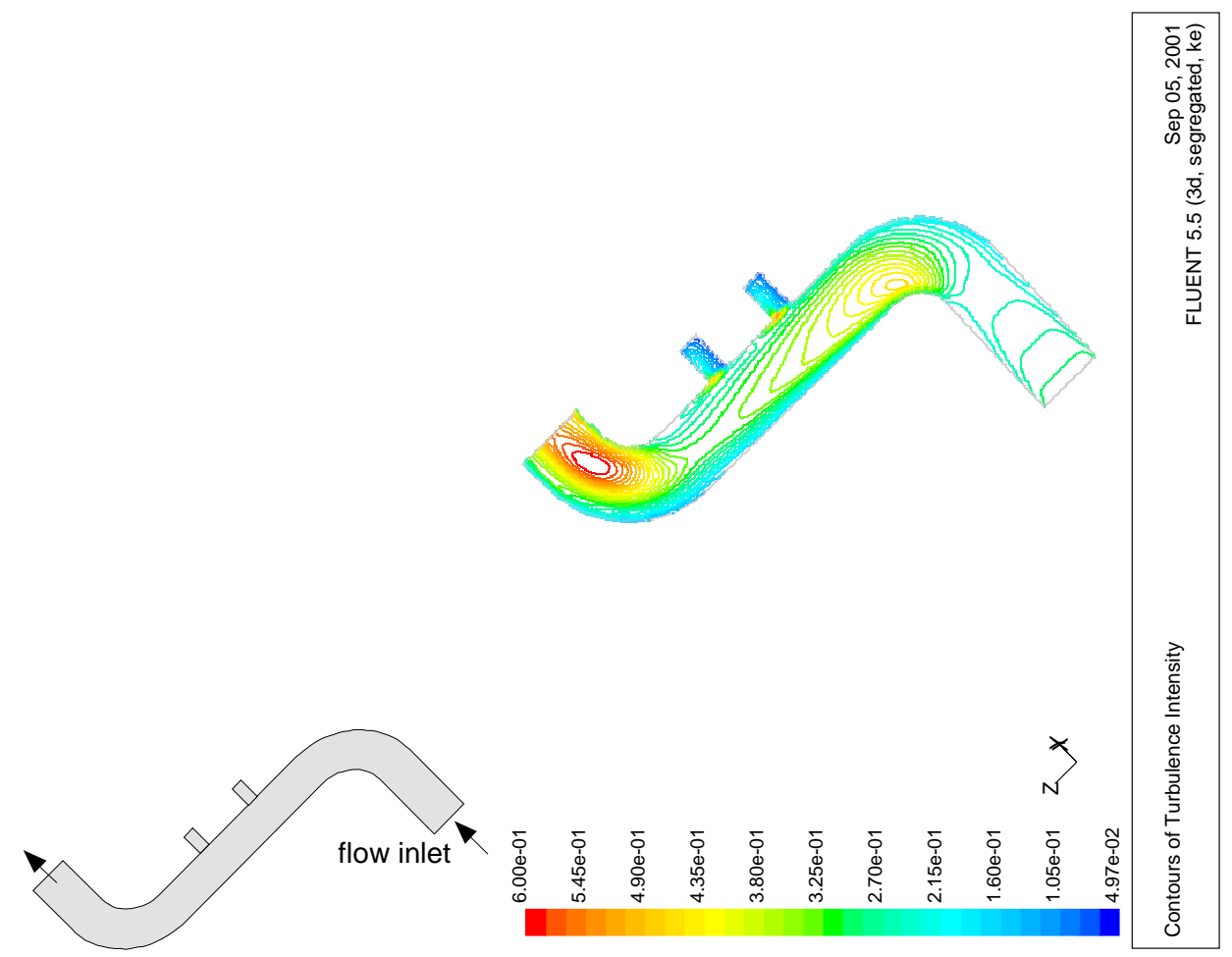

(Case b in Fig 4)

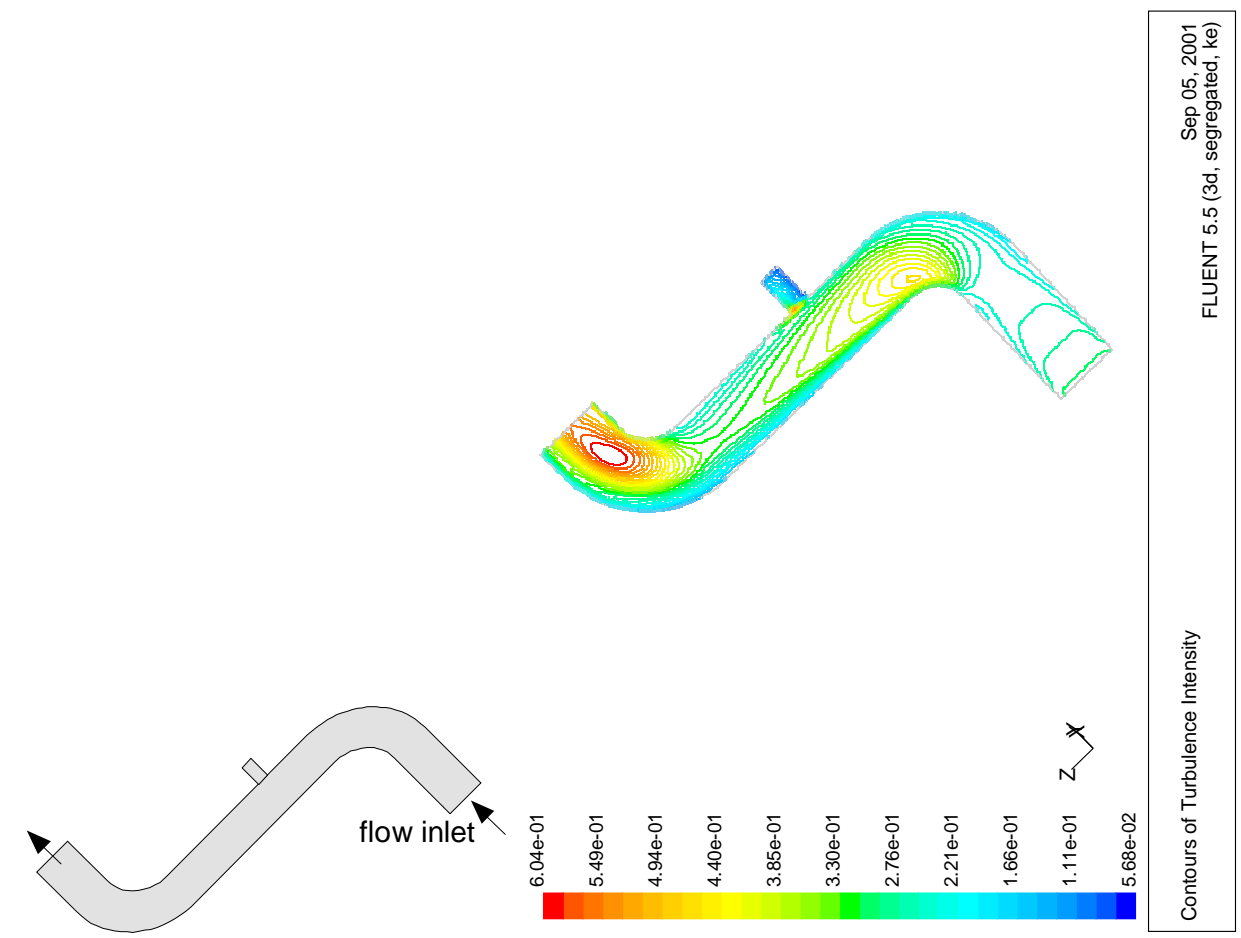

(Case c in Fig. 4)

Figure 20. Comparison of turbulence intensity for two cases associated with particle dispersion. 


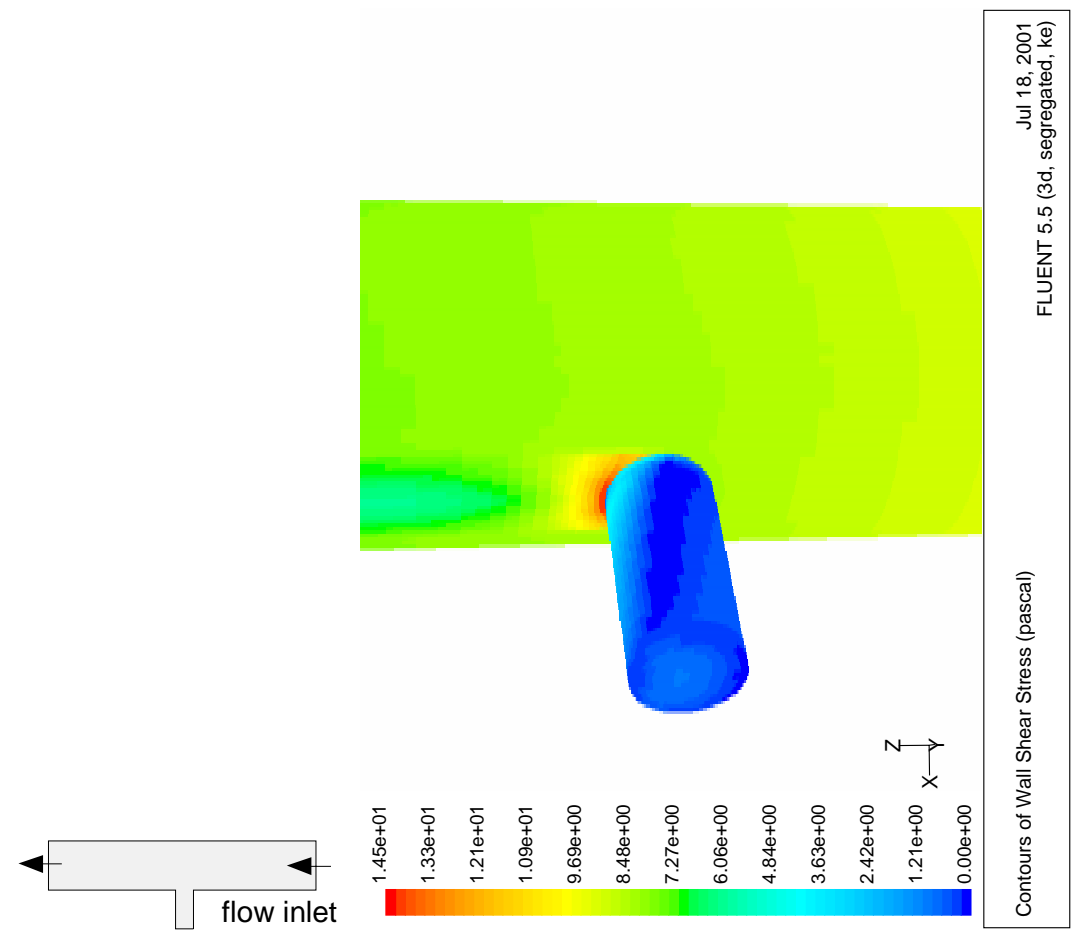

(Wall shear distributions)

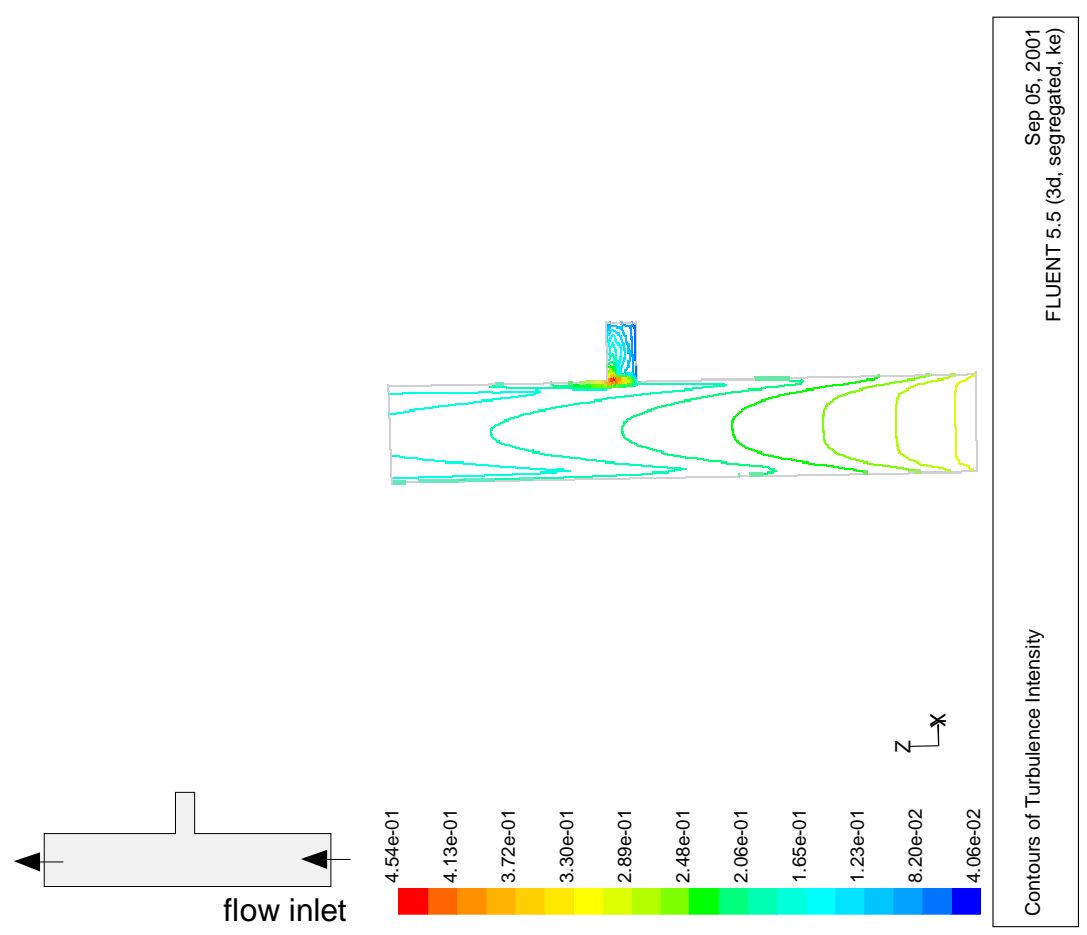

(Turbulence intensity distribution at the center-plane)

Figure 21. Wall shear stress and turbulence intensity distributions for the 36 in long and 10 in diameter pipe with 3 in leg (case g) associated with wall erosion. 
Report: WSRC-TR-2001-00591 Rev 0 SRT-RPP-2001-00227 Rev 0

Date: $\quad 04 / 05 / 02$

Page: 42 of 60
WESTINGHOUSE SAVANNAH RIVER COMPANY

DESIGN ANALYSIS FOR A SCALED EROSION TEST

Table 8. Maximum wall shear stresses for the models of the filter component associated with erosion (filter tube diameter $=0.5 \mathrm{in}$ )

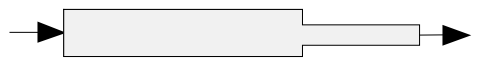

(One-tube equivalent filter model)

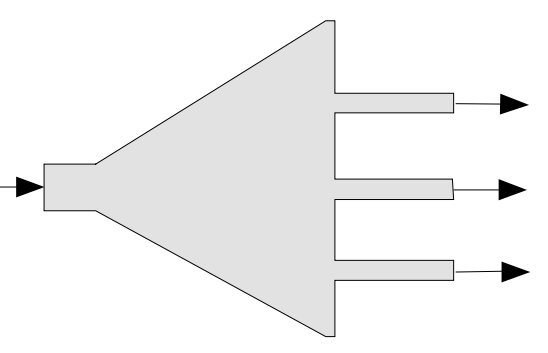

(7-tube equivalent filter model)

\begin{tabular}{|c|c|c|}
\hline Cases & $\begin{array}{c}\text { One-tube equivalent model } \\
\text { (case-e in Fig. 4) }\end{array}$ & $\begin{array}{c}\text { Seven-tube equivalent model } \\
\text { (case-g in Fig. 4) }\end{array}$ \\
\hline Filter geometry & One tube & 7 tube \\
\hline Filter tube diameter & $0.5 \mathrm{in}$ & 4 in \\
\hline Filter boundary diameter & $7 / 8 \mathrm{in}$ & $171.5 \mathrm{~Pa}$ \\
\hline Max. wall shear & $185.2 \mathrm{~Pa}$ & $\begin{array}{c}\text { Upstream tube sheet } \\
\text { (see Fig. 25) }\end{array}$ \\
\hline $\begin{array}{c}\text { Max. erosion location } \\
\text { due to impingement }\end{array}$ & $\begin{array}{c}\text { Upstream tube sheet } \\
\text { (see Fig. 25) }\end{array}$ & $\sim 0.7$ \\
\hline \begin{tabular}{c} 
Relative scale for erosion \\
\hline
\end{tabular} & 1.0 & \\
\hline
\end{tabular}




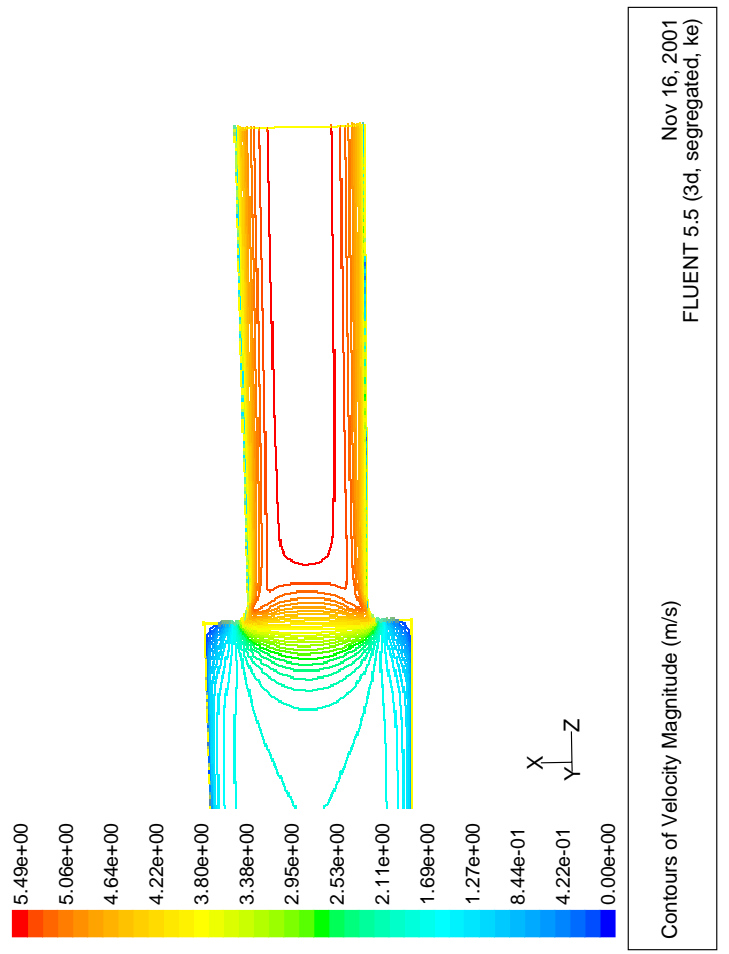

(Velocity contour at the center plane of smooth filter tube)

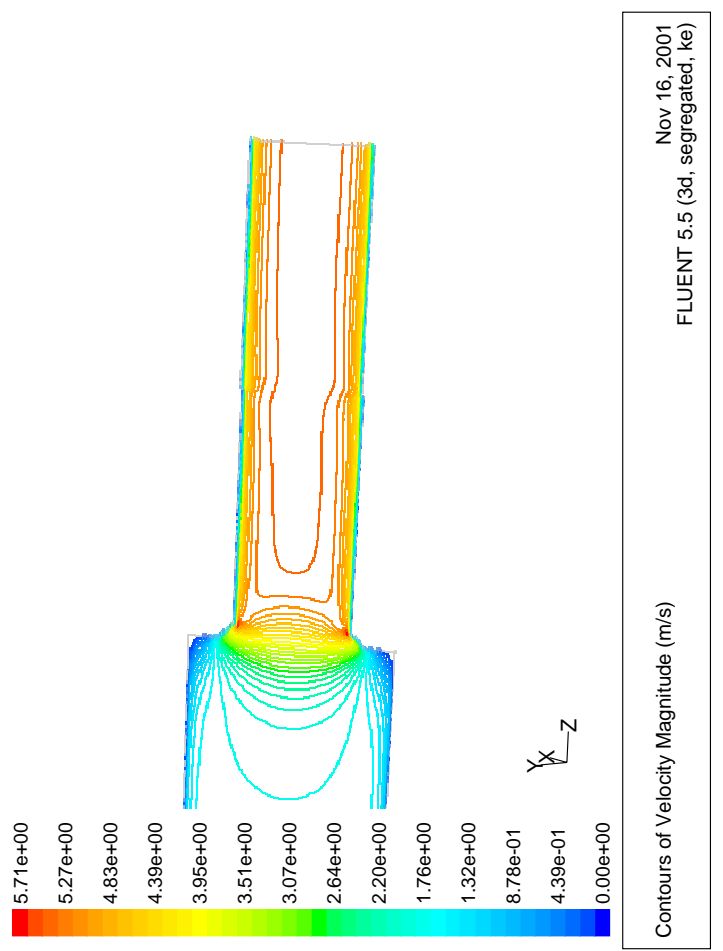

(Velocity contour at the center plane of welded filter tube)

Figure 22. Comparison of velocity distributions at the center planes of the one-tube models with smooth and welded tubes (case-e and case-f in Fig. 4). 
Report: WSRC-TR-2001-00591 Rev 0

WESTINGHOUSE SAVANNAH RIVER COMPANY SRT-RPP-2001-00227 Rev 0

Date: $\quad 04 / 05 / 02$

DESIGN ANALYSIS FOR A SCALED EROSION TEST

Page: $\quad 44$ of 60

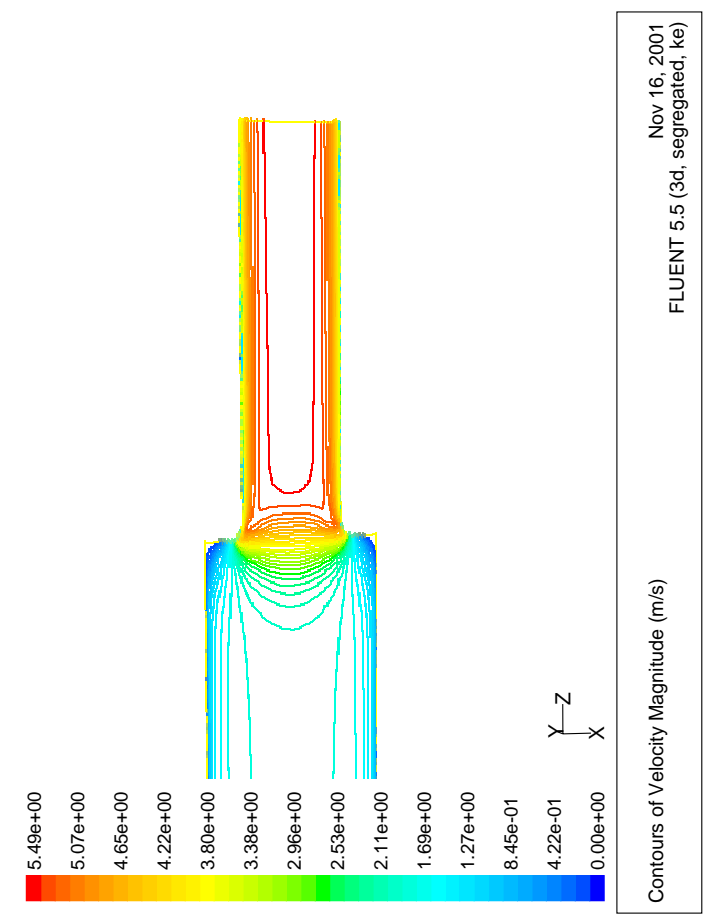

(one-tube filter model)

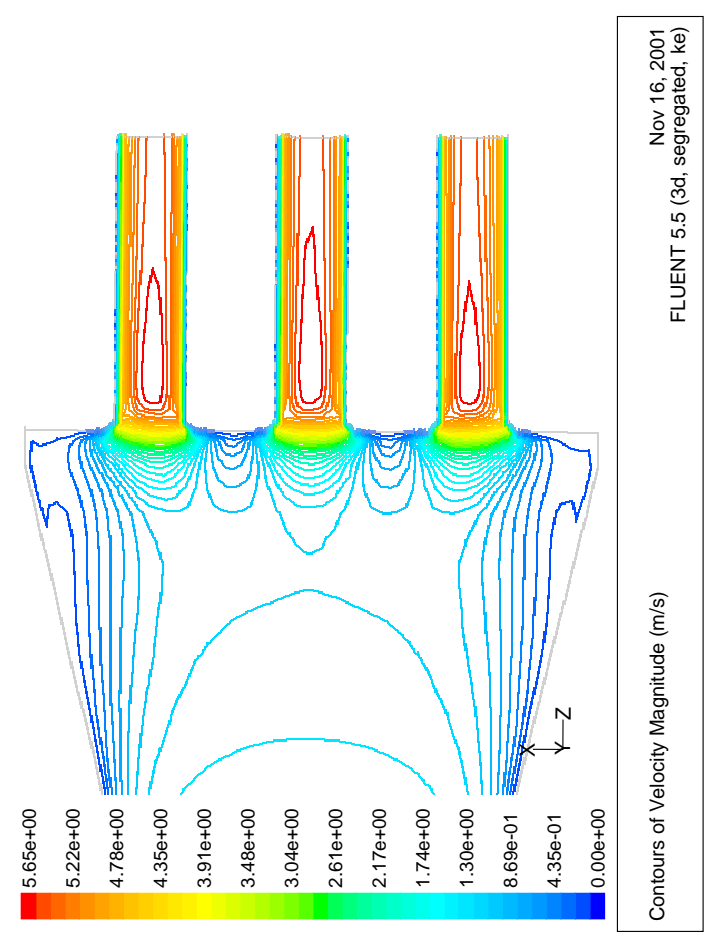

(7-tube filter model)

Figure 23. Comparison of velocity distributions at the center plane of the one-tube and seven-tube filter models to simulate the cross-flow filtration component. 
WESTINGHOUSE SAVANNAH RIVER COMPANY

DESIGN ANALYSIS FOR A SCALED EROSION TEST
Report: WSRC-TR-2001-00591 Rev 0 SRT-RPP-2001-00227 Rev 0

Date:

Page:

$04 / 05 / 02$

45 of 60

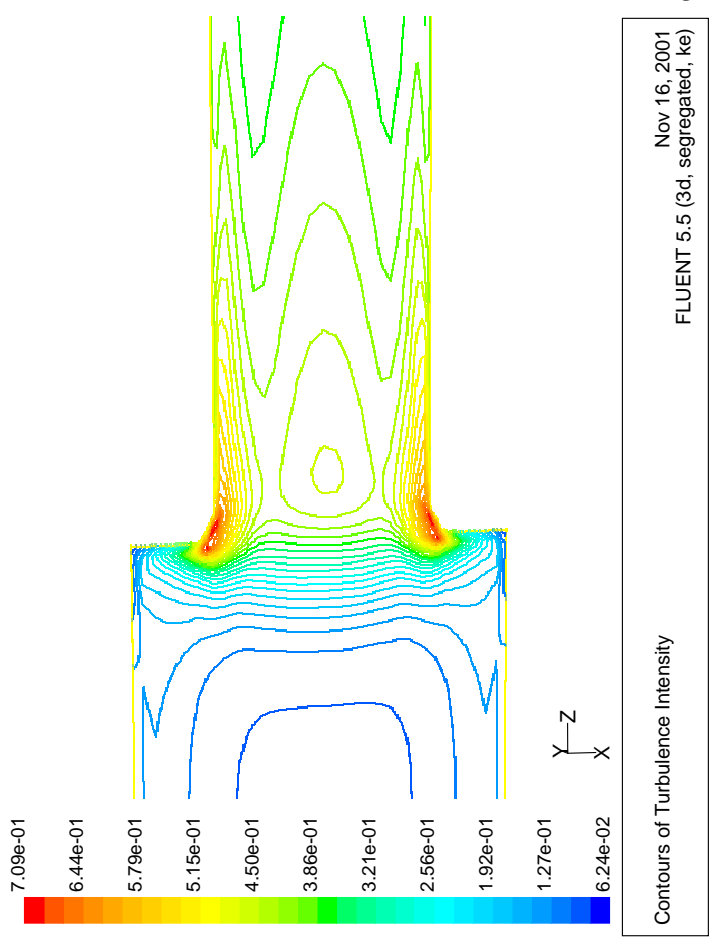

(one-tube filter model)

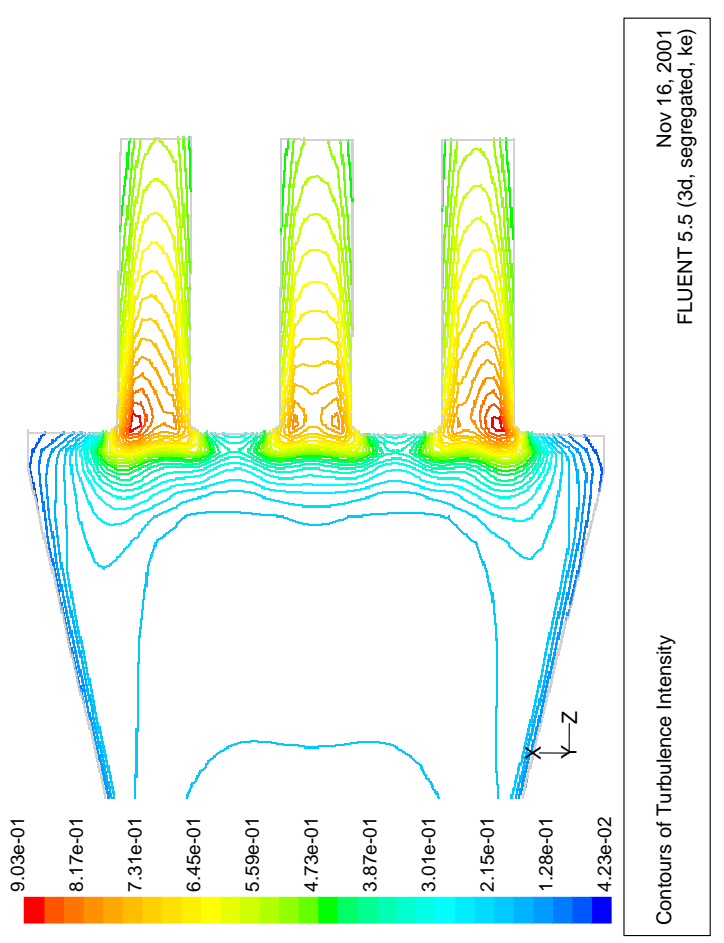

(7-tube filter model)

Figure 24. Comparison of turbulence intensity distributions at the center plane of the one-tube and seven-tube filter models to simulate the cross-flow filtration component using flow domains and conditions shown in Figs. 7 and 8. 


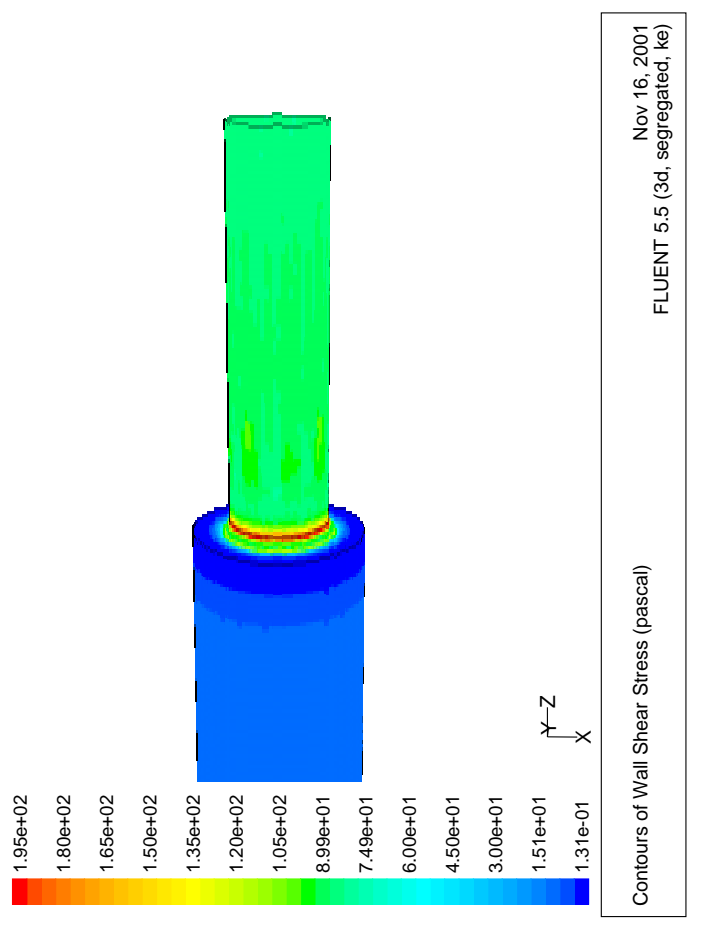

(Wall shear distributions for the one-tube model)

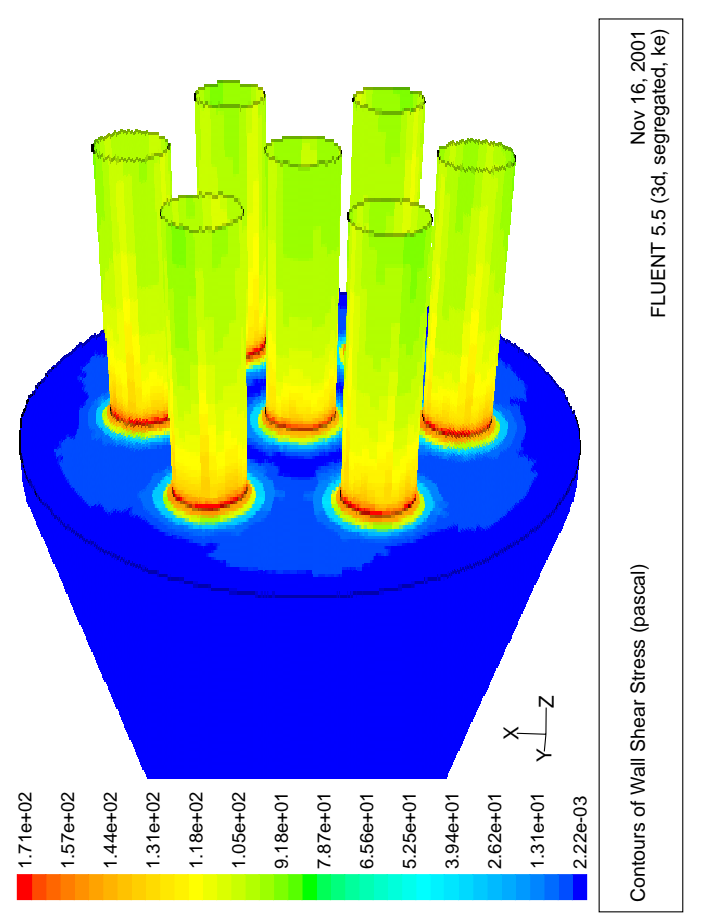

(Wall shear distributions for the 7-tube model)

Figure 25. Comparison of wall shear distributions between one-tube model and 7-tube model to simulate the cross-flow filtration system. 

SRT-RPP-2001-00227 Rev 0

Date: $04 / 05 / 02$ Page: 47 of 60

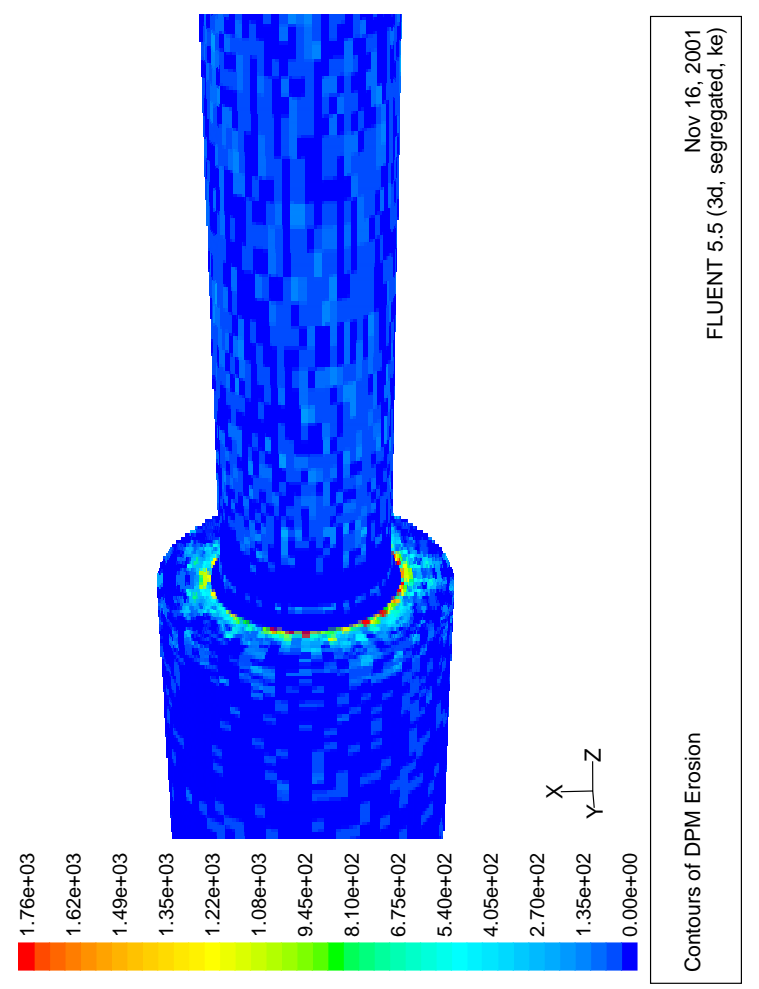

(one-tube filter model representing the case-e geometry)

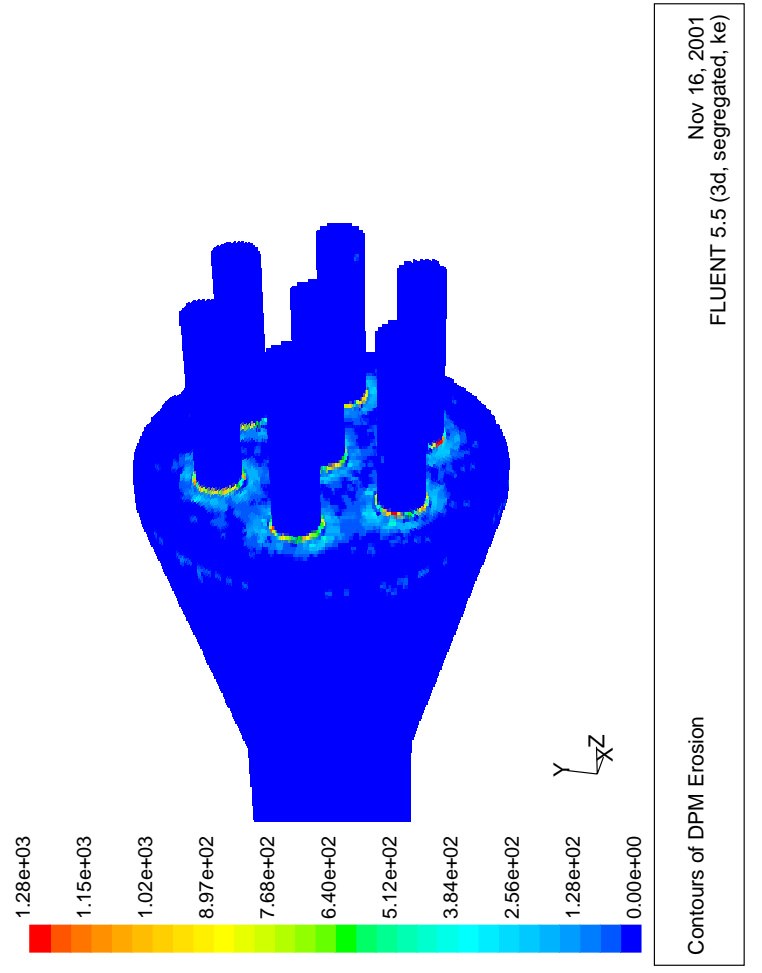

(seven-tube filter model representing the case-g geometry)

Figure 26. Comparison of erosion distributions for the two filter models. 
Report: WSRC-TR-2001-00591 Rev 0

WESTINGHOUSE SAVANNAH RIVER COMPANY SRT-RPP-2001-00227 Rev 0

Date: $\quad 04 / 05 / 02$

DESIGN ANALYSIS FOR A SCALED EROSION TEST

Page: $\quad 48$ of 60

Potential max. erosion location

(-.-_) Max. turbulence intensity location

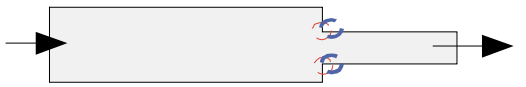

(Geometry representing case-e component in Fig. 4)

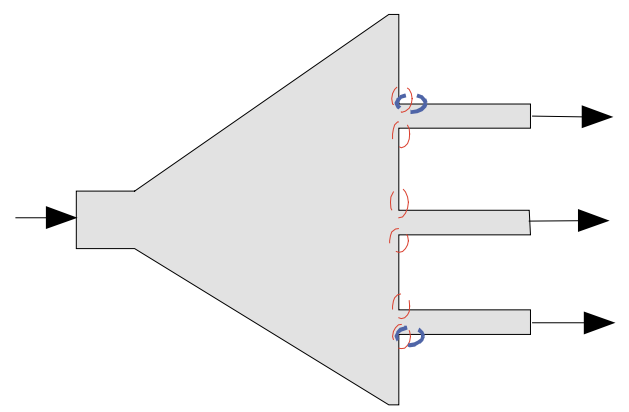

(Geometry representing case-g component in Fig. 4)

Figure 27. Potential maximum erosion locations at the middle planes of one-tube (casee) and seven-tube filter (case-g) components of the cross-flow filtration facility predicted by the present model.

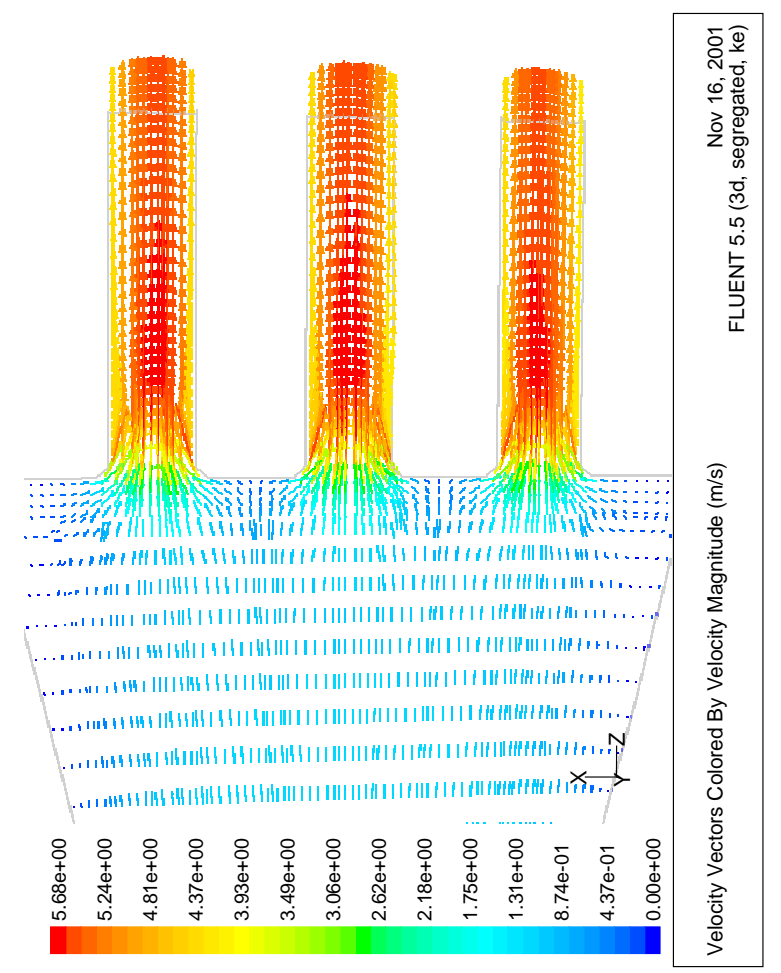

Figure 28. Velocity vector plot at the center plane of the 7-tube model. 
Date:

$04 / 05 / 02$

Page:

49 of 60

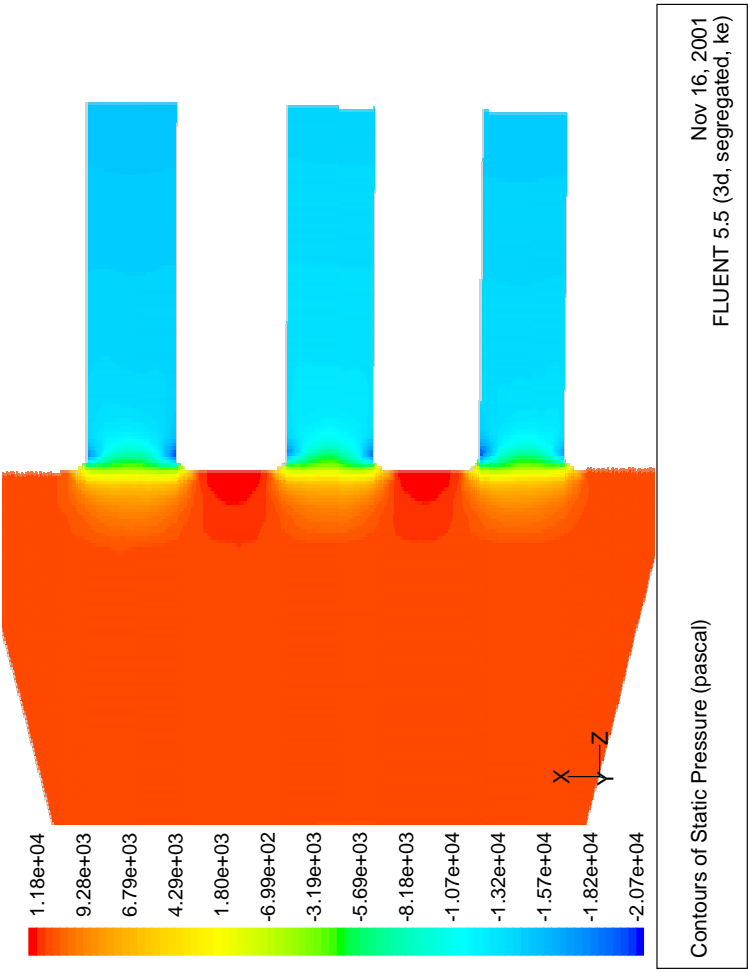

Figure 29. Pressure distributions at the center plane of the 7-tube model.

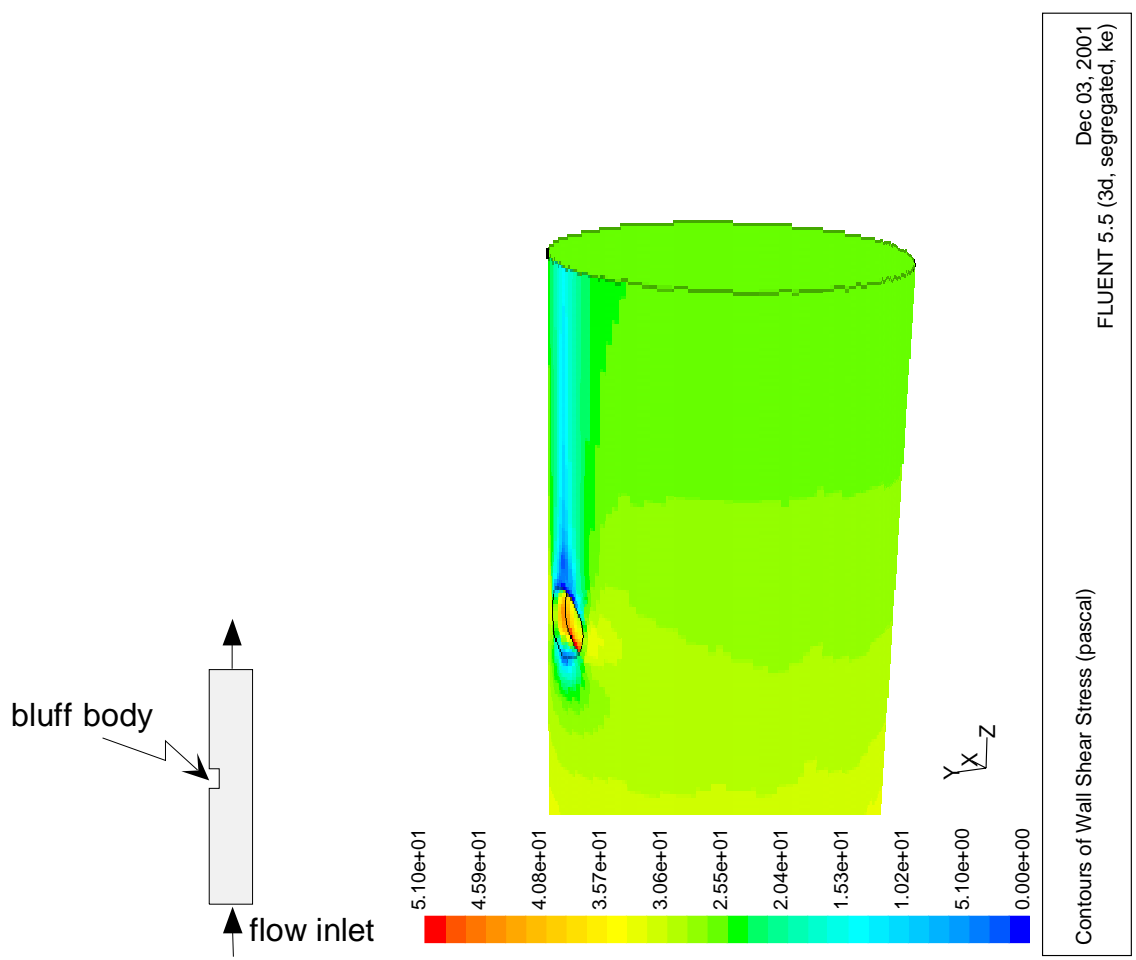

Figure 30. Wall shear distributions for the bluff body (case-i in Fig 4) predicted by the present model. 
Report: WSRC-TR-2001-00591 Rev 0 SRT-RPP-2001-00227 Rev 0

Date: $\quad 04 / 05 / 02$

Page: 50 of 60
WESTINGHOUSE SAVANNAH RIVER COMPANY

DESIGN ANALYSIS FOR A SCALED EROSION TEST
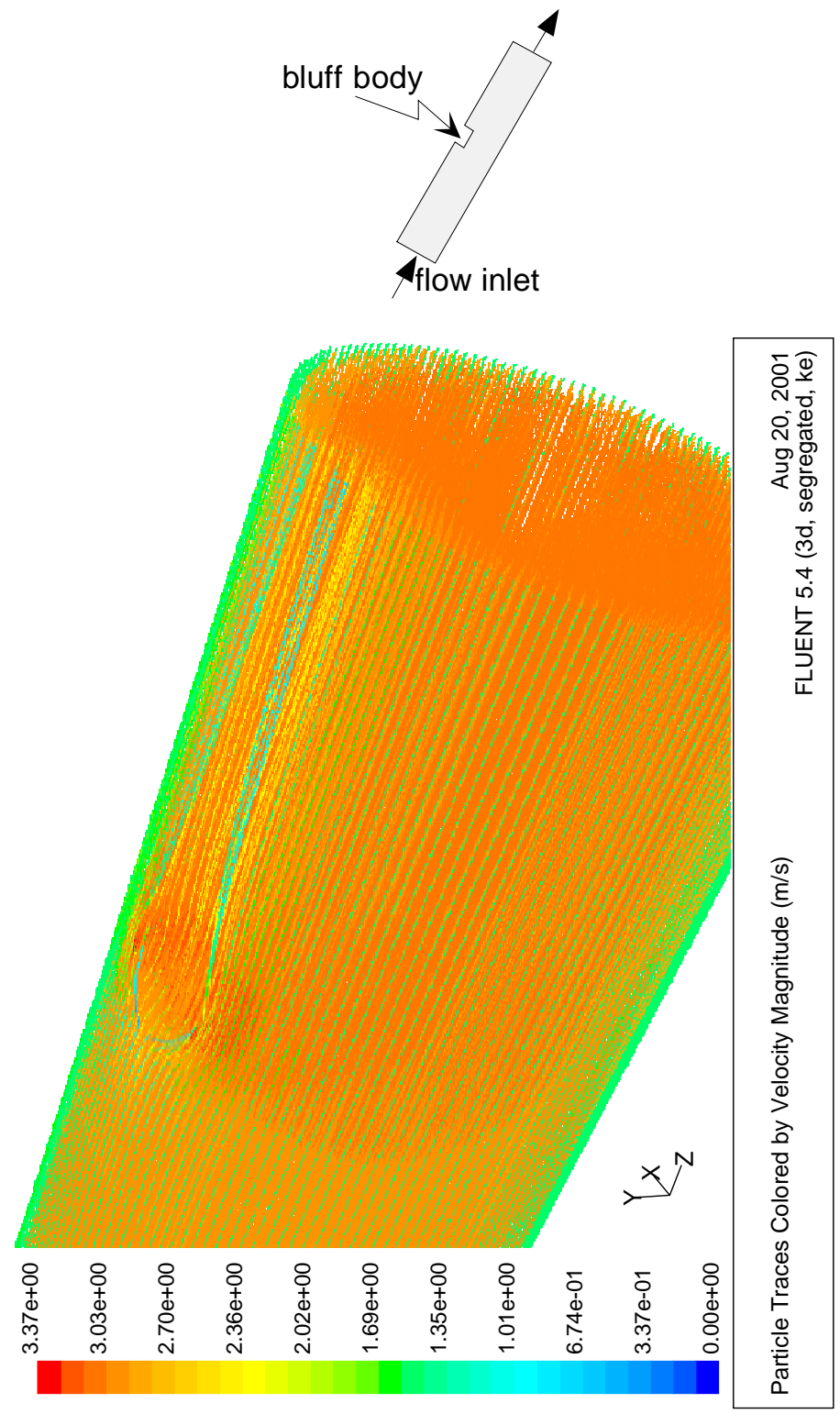

Figure 31. Particle trajectories for the bluff body inside the straight pipe (case-i in Fig 4) predicted by the particle impingement model. 


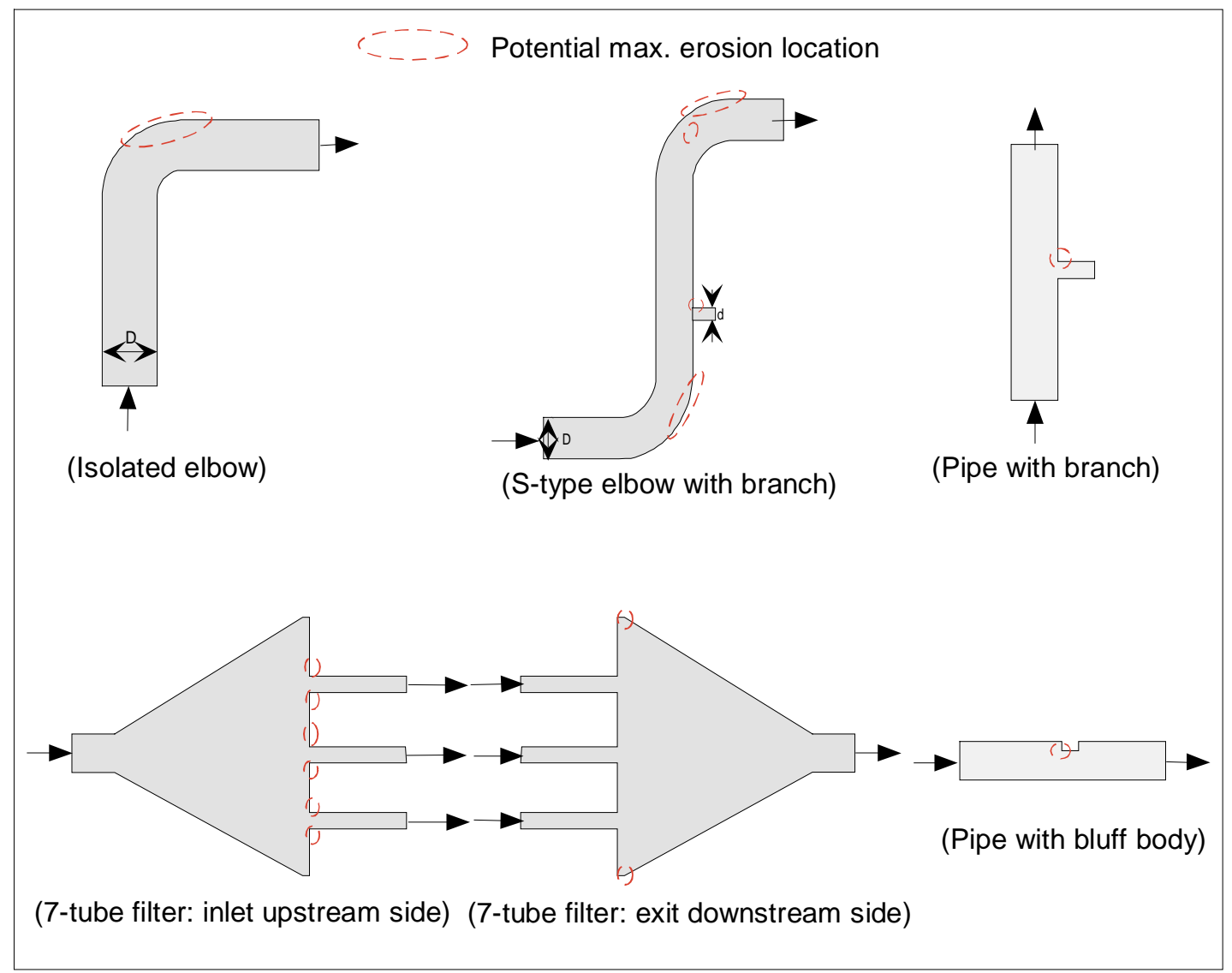

Figure 32. Potential maximum erosion locations at the middle planes of key components of the cross-flow filtration facility selected by the present model.

Table 9. Maximum wall shears for the models of the key components considered in the analysis associated with erosion (filter tube diameter $=0.5 \mathrm{in}$ )

\begin{tabular}{|c|c|c|c|c|c|}
\hline \multirow{2}{*}{ Cases } & \multirow{2}{*}{$\begin{array}{l}\text { Isolated } \\
\text { elbow } \\
(\text { case-a* })\end{array}$} & \multirow{2}{*}{$\begin{array}{l}\text { Two elbows } \\
\text { with branch } \\
(\text { case-c* })\end{array}$} & \multicolumn{2}{|c|}{ 7-tube filter } & \multirow{2}{*}{$\begin{array}{l}\text { Pipe with } \\
\text { bluff body } \\
(\text { case-i* })\end{array}$} \\
\hline & & & $\begin{array}{c}\text { Inlet } \\
(\text { case-g*) }\end{array}$ & $\begin{array}{c}\text { Exit } \\
\left(\text { case- } h^{*}\right)\end{array}$ & \\
\hline $\begin{array}{l}\text { Max. wall shear } \\
(\mathrm{Pa})\end{array}$ & 72.0 & 66.2 & 171.5 & 115.8 & 51.0 \\
\hline $\begin{array}{l}\text { Max. erosion } \\
\text { location due to } \\
\text { impingement } \\
\text { (see Fig. 31) }\end{array}$ & $\begin{array}{l}\text { Outer } \\
\text { elbow }\end{array}$ & Outer elbow & $\begin{array}{l}\text { Upstream } \\
\text { tube sheet }\end{array}$ & $\begin{array}{l}\text { Downstream } \\
\text { tube sheet }\end{array}$ & Front bluff \\
\hline $\begin{array}{l}\text { Relative }^{* *} \text { scale } \\
\text { for max. } \\
\text { erosion rate }\end{array}$ & $\sim 0.4$ & $\sim 0.9$ & 1.0 & $\sim 0.1$ & $\sim 0.3$ \\
\hline
\end{tabular}

Note: * Each case is identified in Fig. 4.

** The scale is relative to the maximum erosion rate of case-g. 


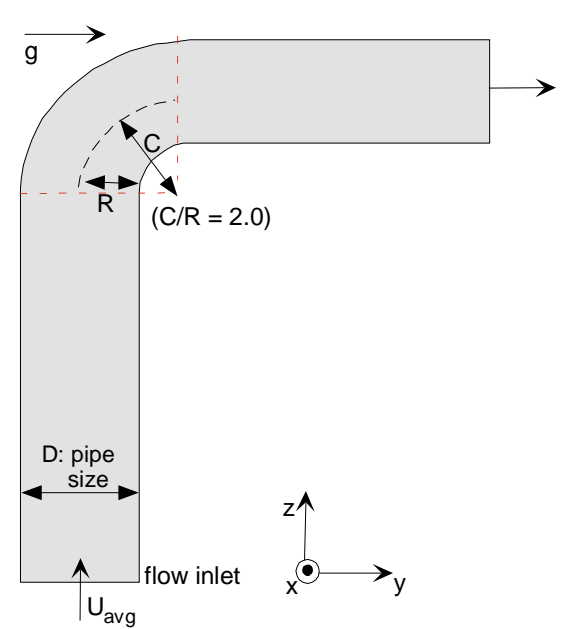

Elbow orientations

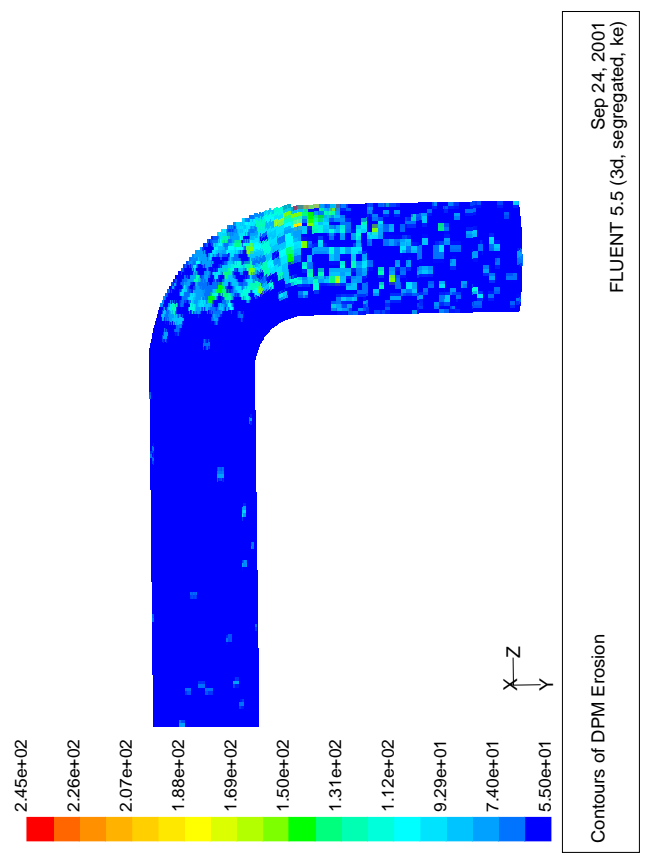

3in scaled elbow $\left(U_{\text {avg }}=3.5 \mathrm{~m} / \mathrm{sec}\right)$

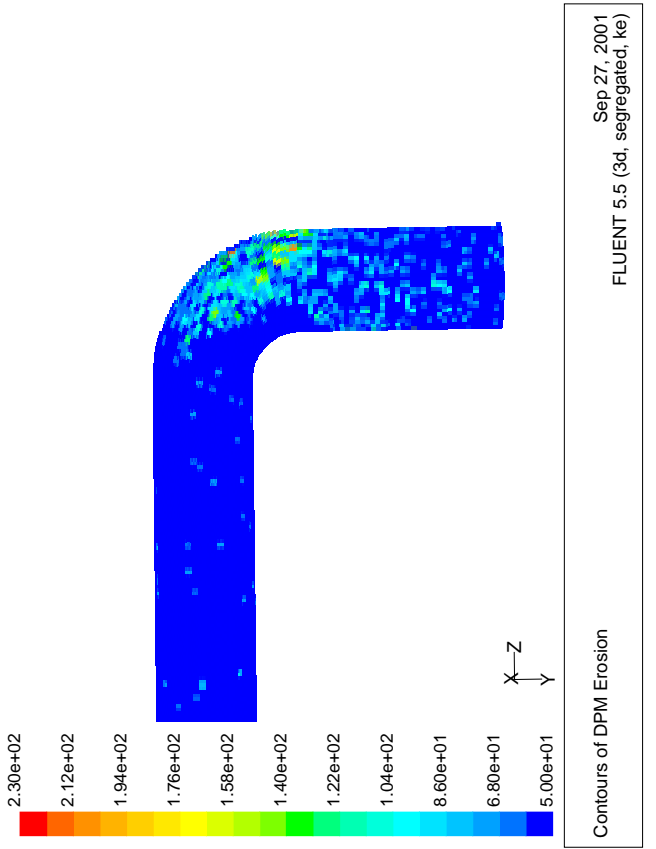

10in full-scale elbow $\left(\bigcup_{\text {avg }}=2.99 \mathrm{~m} / \mathrm{sec}\right)$

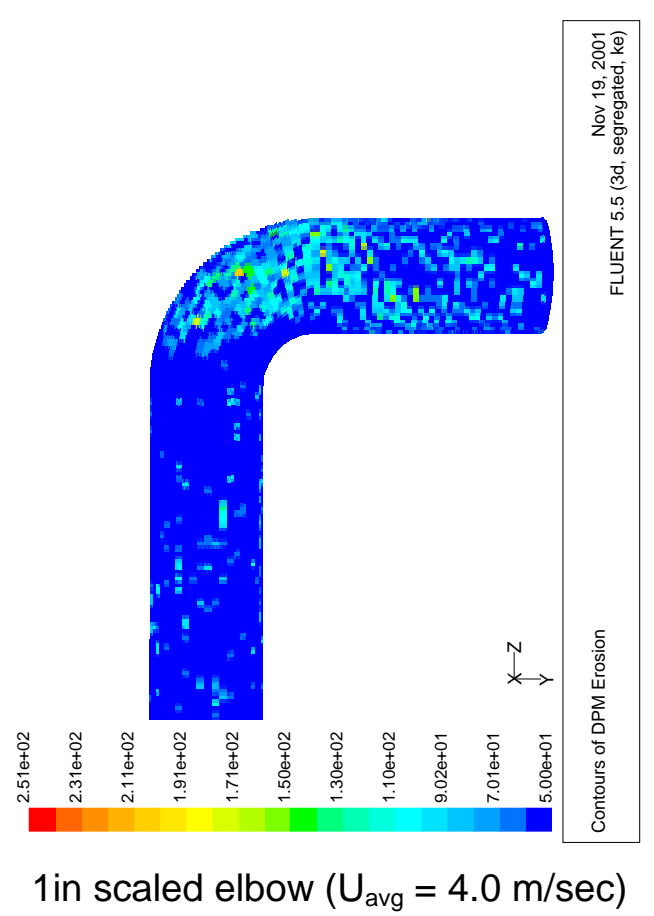

Figure 33. Comparison of the erosion distributions due to particle impingement under three different scaled elbow components 
Date:

Page:

$04 / 05 / 02$

53 of 60

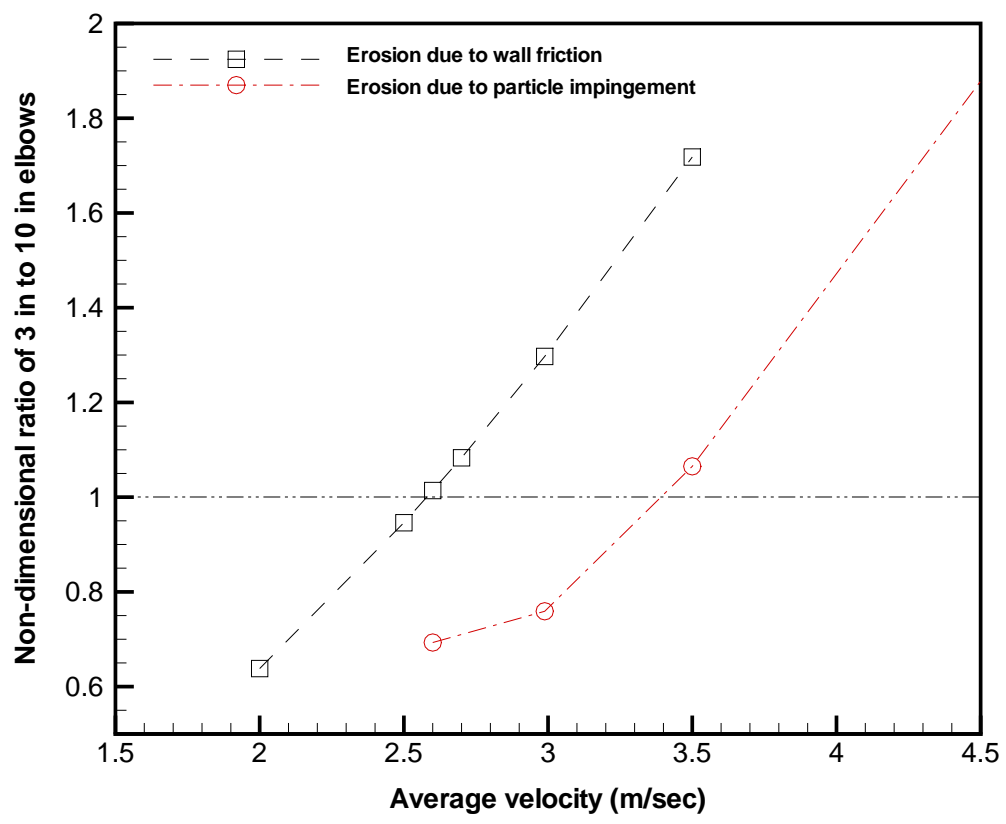

(3 in size)

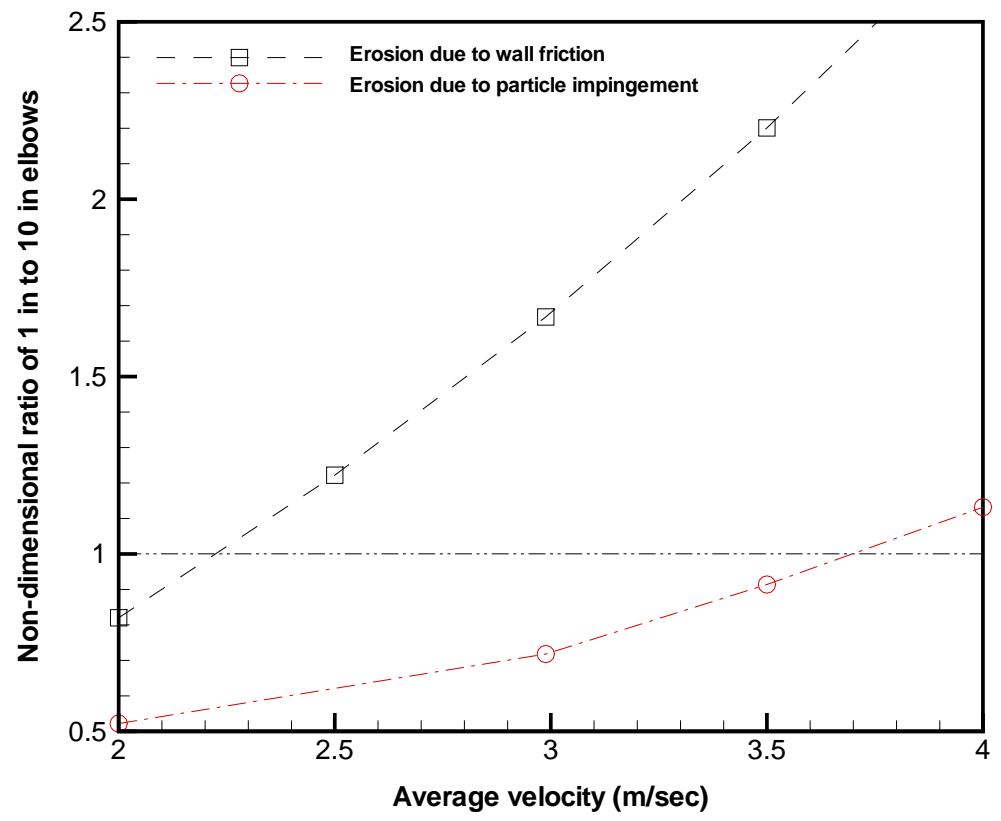

(1 in size)

Figure 34. Nondimensional erosion ratio of scale-down (3 in and $1 \mathrm{in}$ ) to 10 in prototypic elbow for various slurry velocities 
Report: WSRC-TR-2001-00591 Rev 0

WESTINGHOUSE SAVANNAH RIVER COMPANY SRT-RPP-2001-00227 Rev 0

Date: $\quad 04 / 05 / 02$

DESIGN ANALYSIS FOR A SCALED EROSION TEST

Page: 54 of 60

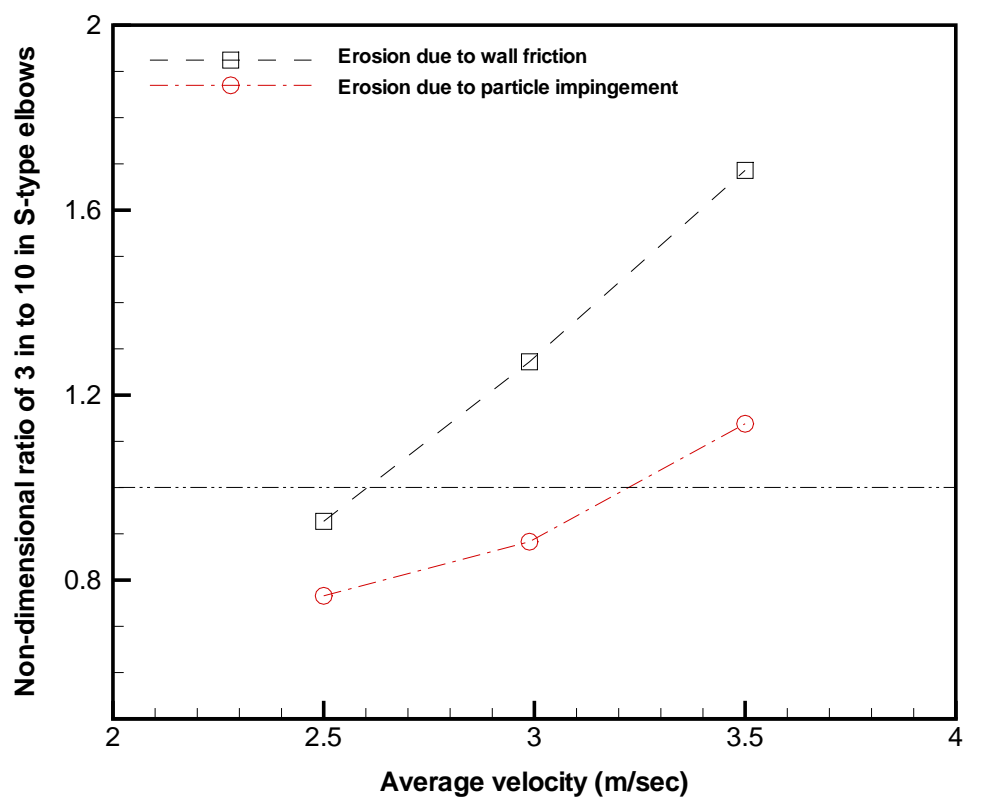

(3 in pipe size)

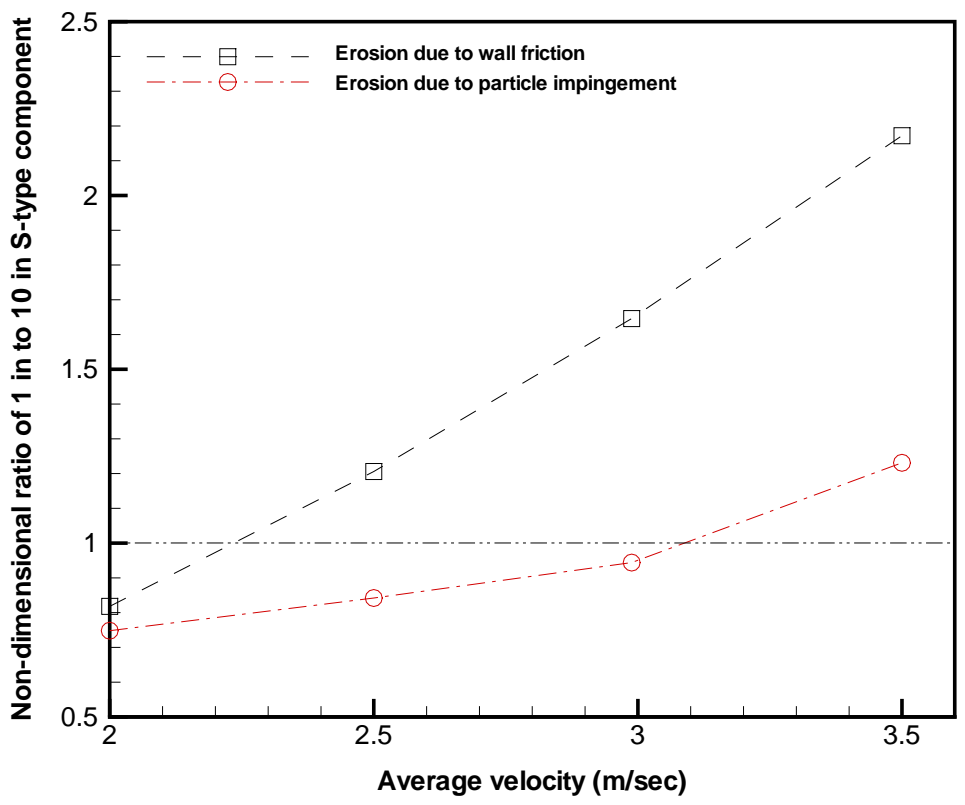

(1 in pipe size)

Figure 35. Nondimensional erosion ratio of scale-down (3 in and $1 \mathrm{in})$ to 10 in prototypic S-type pipings for various slurry velocities 


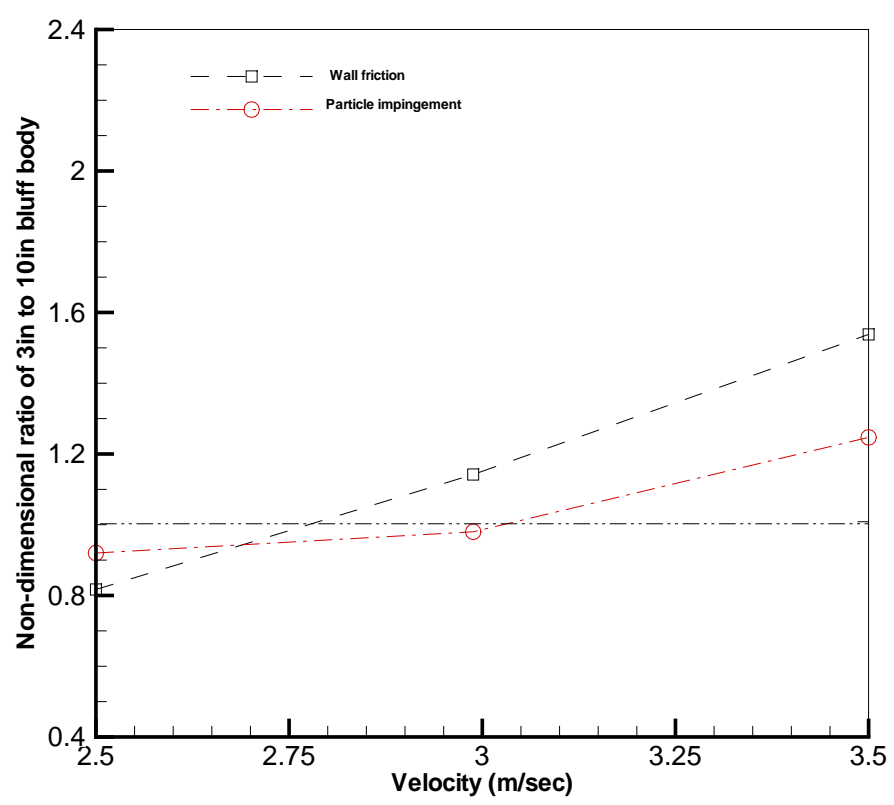

(3 in size)

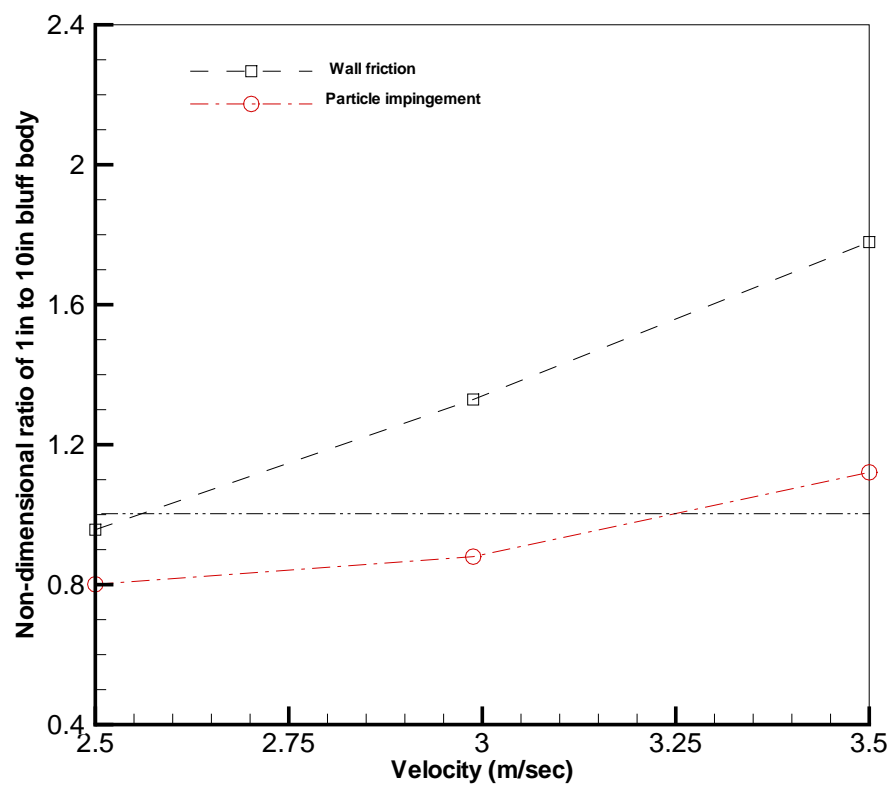

(1 in size)

Figure 36. Nondimensional erosion ratio of scale-down (3 in and 1 in) to 10 in prototypic bluff body for various slurry velocities 
Date: $\quad 04 / 05 / 02$

DESIGN ANALYSIS FOR A SCALED EROSION TEST

Page: $\quad 56$ of 60

\section{Conclusions}

This report presents the application of computational fluid dynamics (CFD) methods to ensure that the test facility design would capture the erosion phenomena expected in the full-scale cross-flow ultrafiltration facility. The present models assume that there are two manners in which a wall surface is worn. The first is based on the homegeneous solid-fluid model, and its basic mechanism is that wall friction of the mixed slurry on the abraded surface can cause wear. The other is that some particles impinged on the wall surface are able to cut chips out of the impacted surface. For the present work, Eulerian continuous transport equations and Lagrangian momentum balance for the solid phase dispersed in the slurry flow were used to estimate wall shear and particleimpinged erosions. For typical operating conditions of the facility, Reynolds number is about $10^{5}$ corresponding to fully-turbulent flow regime. Two-equation turbulence model was used to consider the dispersion effect of particles due to turbulent eddies. In the present calculations, solids content of the working fluid, the regions of high wall shear, and particle impingement with the walls were considered as major mechanisms associated with the erosion.

Three sets of representative experiments were chosen to test the CFD models presented in this work. All these tests were performed using sand-water slurry. The benchmarking results against the literature data for hydraulic transport and erosion tests are reasonably good taking into account the complex nature of fluid-solid two-phase phenomena.

The CFD analyses were then designed to characterize slurry-flow profiles, wall shear, and particle impingement distributions in key pipe bends and fittings representative of the filtration system. Pipe diameters, lengths, the locations of pipe fittings, and slurry velocities were scaled with the CFD calculations to ensure that the erosion drivers in the test facility were representative of the full-scale facility. To be conservative, the highest velocity over full-scale value $(9.8 \mathrm{ft} / \mathrm{sec})$ will be used, that is, $3.4 \mathrm{~m} / \mathrm{sec}(11.2 \mathrm{ft} / \mathrm{sec})$ for the 3 in test loop (14\% over full-scale) and $3.7 \mathrm{~m} / \mathrm{sec}(12.1 \mathrm{ft} / \mathrm{sec})$ for the 1 in test loop (24\% over full-scale). The results are also shown in Fig. 34.

From the present analysis results, main conclusions are drawn as follows:

- The prediction results show that when the slurry velocity increases, wall shear stress closely related to the abrasive erosion is more sensitive to the scaling of pipe size, compared to that of particle impingement behavior.

- The analysis results show that erosion decreases with increasing turbulence intensity, leading to the increased radial dispersion of slurry. This is consistent with the literature information.

- All the main loop components of the cross-flow filtration facility were studied to simplify the components without losing key erosion phenomena and slurry flow characteristics expected in the full-scale facility. Key components selected by the present analysis are isolated elbow, two-elbow connected closely with single branch, seven-tube filter arrangement, and bluff body attached to the inner wall of horizontal pipe.

- The present computational models determined operating flow conditions for the scaled test facility to ensure that the erosion behaviors expected at the full-scale 
facility are properly captured in the scale-down test facility. In this case, three different component configurations were applied for the scaling considerations under three different size conditions, including 10 in prototypic scale, 3 in and 1 in test scales.

- The locations of high erosion, which were predicted by the particle impingement model for each of the selected components, provided the guidance for erosion measurement under scaled test facility.

- From the benchmarking of the present CFD models against the literature data, the model predictions agree with the test data within about $15 \%$.

When the test results from the scaled experiment facility at SRTC are available, the present models will be benchmarked in more detail. This results in a validation of those calculations, and will allow the test results to be applied to a quantitative estimation of erosion over the entire plant lifetime of the full-scale filtration facility. 


\section{References}

1. Duignan, M. R., "Slurry Wear Evaluation of the Pretreatment Cross-flow Filtration and Evaporation Systems", WSRC-TR-2001-00145, SRT-RPP-2001-000038, Rev. 0, October 15, 2001.

2. Duignan, M. R., "Computational Assistance for the Slurry Wear Evaluation of the Pretreatment Cross-flow Filtration and Evaporation Systems", WSRC-TR-200100194, SRT-RPP-2001-000041, Rev. 0, June 11, 2001.

3. Duignan, M. R. and Lee, S. Y., "RPP-WTP Slurry Wear Evaluation: Literature Review", Savannah River Technology Center, WSRC-TR-2001-00156, SRT-RPP2001-00033, March 21, 2001.

4. Duignan, M. R. ,"RPP-WTP Slurry Wear Evaluation: Slurry Abrasivity," Savannah River Technology Center, WSRC-TR-2002-00062, SRT-RPP-2002-00022, January 31, 2002.

5. Burstein, G.T. and Sasaki, K., Effect of impact angle on the slurry erosion-corrosion of 304L stainless steel. Wear 240, 80-94, 2000.

6. Eibling, R.E. and Nash, C.A., Hanford waste simulants created to support the research and development on the River Protection Project - Waste Treatment Plant. Westinghouse Savannah River Company Report No. WSRC-TR-2000-00338, 2000.

7. Elmore, M.R., "imulant Erosion Testing", Battelle Pacific Northwest National Laboratory Report No. WTP-RPT-001, 2000.

8. Finnie, I., "Some reflections on the past and future of erosion", Wear, vol. 186, pp. 110, 1995.

9. FLUENT, Fluent, Inc., Lebanon, New Hampshire, 1998.

10. Foley, T. and Levy, A., "The erosion of heat-treated steels", Wear, vol. 91, pp. 4564, 1983.

11. Gandhi, B.K., Singh, S.N., and Seshadri, V., "Study of the parametric dependence of erosion wear for the parallel flow of solid-liquid mixtures", Tribology International, vol. 32, pp. 275-282, 1999.

12. Golcar, G.R., Brooks, K.P., Darab, J.G., Davis, J.M., and Jagoda, L.K., "Development of inactive high-level waste envelope D Simulant for scaled crossflow filtration testing", Battelle Pacific Northwest National Laboratory Report No. PNWD3042, 2000.

13. Graf, W. H., Hydraulics of Sediment Transport, McGraw-Hill Book Company, New York, 1971.

14. Hisamitsu, N., Iseh, T., and Takeishi, Y., "An experimental study on pipe erosion by sand slurry", Proc. $6^{\text {th }}$ Conference on Slurry Transportation, Slurry Transport Association, pp. 319-332, 1981.

15. Iwai, Y. and Nambu, K., "Slurry wear properties of pump lining materials", Wear, vol. 210, 211-219, 1997. 
16. Masayuki, T., Norio, K., Shozaburo, S., and Siro, M., "Hydraulic Conveying of Solids thruough Pipe Bends", J. of Chemical Engineering of Japan, vol. 5, No. 1, pp. 4-13, 1972.

17. Mills, D. and Mason, J.S., "Conveying velocity effects in bend erosion", J. Pipelines, vol. 1, pp. 9-81, 1981.

18. Mishra, A. and Finnie, I., "On the size effect in abrasive and erosive wear", Wear, vol. 65, pp. 359-373, 1981.

19. Neilson, J. H. and Gilchrist, A., "An analytical and experimental investigation of the velocities of particles entrained by the gas flow in nozzles", J. of Fluid Mech., vol. 33, pp. 131-149, 1968.

20. Roco, M.C. and Cader, T., "Energy approach for wear distribution in slurry pipelines", Jap. Journal of Multiphase Flow, vol. 4, pp. 2-20, 1990.

21. Roco, M.C and Minani, L.K., "Effect of particle size distribution and gravitation on wear in centrifugal pump castings", ASME Paper No. 89-FE8, 1989.

22. Shook, C.A. and Roco, M.C., Slurry Flow, Publ. Butterworth-Heinemann, 1991.

23. Singh, T., Tiwari, N., and Sundararajan, G., "Room temperature erosion behaviour of 304, 316, and 410 stainless steels", Wear, vol. 145, pp. 77-100, 1991.

24. Smith H.D. and Elmore, M.R., "Corrosion studies of carbon steel under impinging jets of simulated slurries of neutralized current acid waste (NCAW) and neutralized cladding removal waste (NCRW)", Battelle Pacific Northwest National Laboratory Report No. PNL-7816 (also UC-721), January 1992.

25. Zhong, Y. and Minemura, K., "Measurement of erosion due to particle impingement and numerical prediction of wear in pump casing", Wear, vol. 199, pp. 36-44, 1996.

26. Kay, J. M. and Nedderman, R. M., Fluid Mechanics and Transfer Processes, Cambridge University Press, Cambridge, 1985.

27. Ting, K. and Ma, Y. P., The Evaluation of Erosion/Corrosion Problems of Carbon Steel Piping in Taiwan PWR Nuclear Power Plant", Nuclear Engineering and Design, vol. 191, pp. 231-243, 1999.

28. W. M. Kays and M. E. Crawford, Convective Heat and Mass Transfer, Second Edition, McGraw-Hill Book Company, New York, 1980.

29. Humphrey, J. A. C., "Fundamentals of Fluid Motion in Erosion by Soli Particle Impact", Int. J. of Heat and Fluid Flow, vol. 11, No. 3, pp. 170-195, 1990.

30. Newitt, D. M., Richardson, J. F., Abbott, M., and Turtle, R. B., "Hydraulic Conveying of Solids in Horizontal Pipes", Tans. Instn Chem. Engineers, vol. 33, pp. 93-113, 1955.

31. Lee, S. Y. and Dimenna, R. A., "Validation Analysis for the Calculation of a Turbulent Free Jet in water Using CFDS-FLOW3D and FLUENT (U)", WSRC-TR-95-0170, May 1995.

32. H. Schlichting, Boundary Layer Theory, McGraw-Hill Book Company, New York, 1967. 
Report: WSRC-TR-2001-00591 Rev 0 SRT-RPP-2001-00227 Rev 0

Date: $\quad 04 / 05 / 02$

Page: $\quad 60$ of 60
WESTINGHOUSE SAVANNAH RIVER COMPANY

DESIGN ANALYSIS FOR A SCALED EROSION TEST

33. W. M. Rohsenow and H. Y. Choi, Heat, Mass, and Momentum Transfer, PrenticeHall, Inc., New Jersey, 1961. 